\title{
Análisis de alteraciones murarias y modificaciones relacionales en dos áreas del palacio de Pedro I del Alcázar de Sevilla mediante estudio documental y verificación termográfica
}

\section{Analysis of the wall alterations and relational modifications in two areas of the palace of Pedro within the Alcazar of Seville by means of a documental study and thermographic verification}

\author{
Carmen Moral Ruiz¹, Ana García Bueno², Giuseppe Cultrone ${ }^{3}$ \\ Universidad de Granada \\ Antonio Almagro Gorbea ${ }^{4}$ \\ Escuela de Estudios Árabes (CSIC, Granada)
}

\section{RESUMEN}

El palacio de Pedro I, dentro del Real Alcázar de Sevilla, es un elemento de gran importancia en el urbanismo sevillano. Se dirige esta investigación a esclarecer las intervenciones llevadas a cabo en los vestíbulos de entrada al palacio y en la zona este del Patio de las Doncellas, de forma que se pueda comprender cómo influyeron estos cambios en la compleja articulación de los espacios de la planta baja del palacio en el siglo XIX. Se ha realizado un estudio de las fuentes históricas, tanto gráficas como escritas, para comparar resultados con estudios propios de las ciencias experimentales como la termografía infrarroja. Se han obtenido datos sobre las aperturas realizadas en los paramentos y sus dimensiones, junto con las motivaciones para su ejecución que se relacionan con una mejor circulación e iluminación y con conceptos erróneos sobre la distribución inicial del palacio en su construcción en el siglo XIV.
\end{abstract}

Palabras Clave: paramentos; fotogrametría; termografía infrarroja; palacio Pedro I; Sevilla; siglo XIX.

\begin{abstract}
The Palace of Peter I, inside the Alcazar of Seville, is an element of great importance in Seville urbanism. This piece of research aims at throwing light on the interventions carried out in the entry halls of the Palace as well as in the Dames' Courtyard, in order to facilitate a better understanding of how these alterations influenced the complex articulation of the different spaces on the ground floor of the Palace during the $19^{\text {th }}$ century. A study of historical sources, both graphic and written, have been undertaken in order to compare the results with those typical of experimental sciences such as infrared thermography. Data about the openings carried out in the walls and their dimensions as well as the rationale behind those alterations have been identified. These alterations could be related to the wish to improve circulation and lighting, and also to conceptual mistakes as to how the original distribution of the Palace was when built in the $14^{\text {th }}$ century.
\end{abstract}

Key Words: wall; photogrammetry; infrared thermography; Pedro I Palace; Sevilla; nineteenth-century.

Recibido: 28-06-2017. Aceptado: 05-09-2017. Publicado online: 03/07/2018

Cómo citar este artículo / Citation

Moral Ruiz, C., García Bueno, A., Cultrone, G. y Almagro Gorbea, A. 2018: "Análisis de alteraciones murarias y modificaciones relacionales en dos áreas del palacio de Pedro I del Alcázar de Sevilla mediante estudio documental y verificación termográfica", Arqueología de la Arquitectura, 15: e068. https://doi.org/10.3989/arq.arqt.2018.002

\footnotetext{
carmenmoralruiz@gmail.com / ORCID iD: http://orcid.org/0000-0002-6183-5912

anagar@ugr.es / ORCID iD: http://orcid.org/0000-0001-6201-4510

cultrone@ugr.es / ORCID iD: http://orcid.org/0000-0001-9503-3312

aalmagro@eea.csic.es / ORCID iD: http://orcid.org/0000-0001-9907-5149
} 
Copyright: (c) 2018 CSIC. Este es un artículo de acceso abierto distribuido bajo los términos de la licencia de uso y distribución Creative Commons Reconocimiento 4.0 Internacional (CC BY 4.0)

\section{INTRODUCCIÓN}

El palacio de Pedro I del Real Alcázar de Sevilla, ha sido admirado y estudiado por numerosos investigadores, convirtiéndose en centro de atención de viajeros y eruditos a lo largo de los siglos. Este conjunto ha sufrido desde su primer asentamiento numerosas modificaciones, ya que se buscó amoldar los espacios a las necesidades del momento. Ya en la construcción del palacio de Pedro I se pueden destacar dos directrices a través de las cuales se ejecuta el proyecto, por un lado la utilización de formas y modelos arquitectónicos islámicos y el desarrollo de espacios que buscan satisfacer una funcionalidad distinta de la que se precisaba previamente, mucho más íntima y menos pública (Almagro 2009a). Inicialmente, tras la conquista de Sevilla y el fin del dominio musulmán, Fernando III de Castilla "el Santo" en 1248 (Marín 1990) comienza una labor de inserción de la cultura cristiana en la ciudad y su territorio (Lleó 2013), a los que procura dotar de una serie de construcciones que aportaron el estilo y la estructura urbana cristiana (Marín 1990), pero que en la mayoría de los casos se adaptan a lo previo, siendo el palacio de Pedro I el que inicia un proceso de reorganización del conjunto del Alcázar (Tabales 2010). En esta reorganización que supuso la destrucción de las estructuras iniciales, se observa la proyección de una zona pública y otra privada de forma similar a otros conjuntos de origen musulmán (Almagro 2018). El palacio de Pedro I quedaría separado de las funciones públicas que se dispondrían en el denominado "Cuarto de la Montería" que, aunque no llegó a concluirse, muestra la estructura de sala de corte y salón del trono (Almagro 2018).

El palacio de Pedro I, por su condición de residencia real, ha sufrido numerosas modificaciones que dan lugar a un complejo entramado de elementos arquitectónicos, materiales y técnicas, unas inspiradas en el periodo islámico y otras posteriores debidas a la conquista cristiana y a su propio proceso evolutivo en el campo de la arquitectura palaciega. Estas culturas, cristiana e islámica, son distintas en cuanto a ritos religiosos pero también en relación a las costumbres sociales y funcionamiento de la corte, lo que hacía necesaria la modificación de muchas estancias y accesos. En esta investigación nos centraremos en las actuaciones realizadas en la zona de vestíbulo o entrada al palacio de Pedro I desde el Patio de la Montería y en el área oriental del Patio de las Doncellas, donde se suceden cambios en la estructura y conexiones del palacio, principalmente en el siglo XIX.

\section{METODOLOGÍA}

La metodología se ha establecido en función de las distintas disciplinas que se aplican, entre las que se encuentran la Historia, la Arquitectura, la Arqueología y la Geología a niveles generales. A través de las mismas se estipulan unos pasos a seguir que comienzan con una codificación de las estancias junto con sus paramentos, ya que es fundamental a la hora de mejorar la comprensión de los espacios el evitar la repetición de nombres históricos que en ocasiones van variando a lo largo de los siglos para cada estancia. Dicha codificación establece la división de la planta baja del palacio de Pedro I en veintidós estancias y tres pasillos de acceso (Fig. 1). Tras esta división se procedió a la observación directa a través de un estudio fotogramétrico de cada área que da lugar a una serie de proyecciones $u$ ortofotos de cada uno de los paramentos. Las ortofotos nos sirven como medio de estudio y elementos imprescindibles para la representación de los resultados tanto de estado de conservación, cartografías de procesos de degradación e hipótesis de intervenciones, así como medio de documentación general de la edificación.

Tras haber realizado la aproximación in situ que nos permitió conocer la morfología del palacio, se pasó a desarrollar una labor de documentación histórica que parte tanto de testimonios de la época de estudio e investigaciones actuales que se sirven de documentación de archivo, como de la documentación gráfica disponible, dibujos, grabados, pinturas y fotografías de diversa índole y procedencia, a las que se recurre para estipular áreas de interés en las que se hayan realizado procesos de intervención. Basándose en esta documentación previa que señala zonas de interés para el estudio de las modificaciones en las aperturas de los paramentos, se realizó un estudio mediante termografía infrarroja que permite observar anomalías que esclarecen ciertos procesos y apoyan hipótesis formuladas a partir de la documentación histórica.

El estudio mediante termografía infrarroja se basa en la temperatura y su relación con la energía electromagnética que emite un cuerpo (Gómez-Heras 2012). 


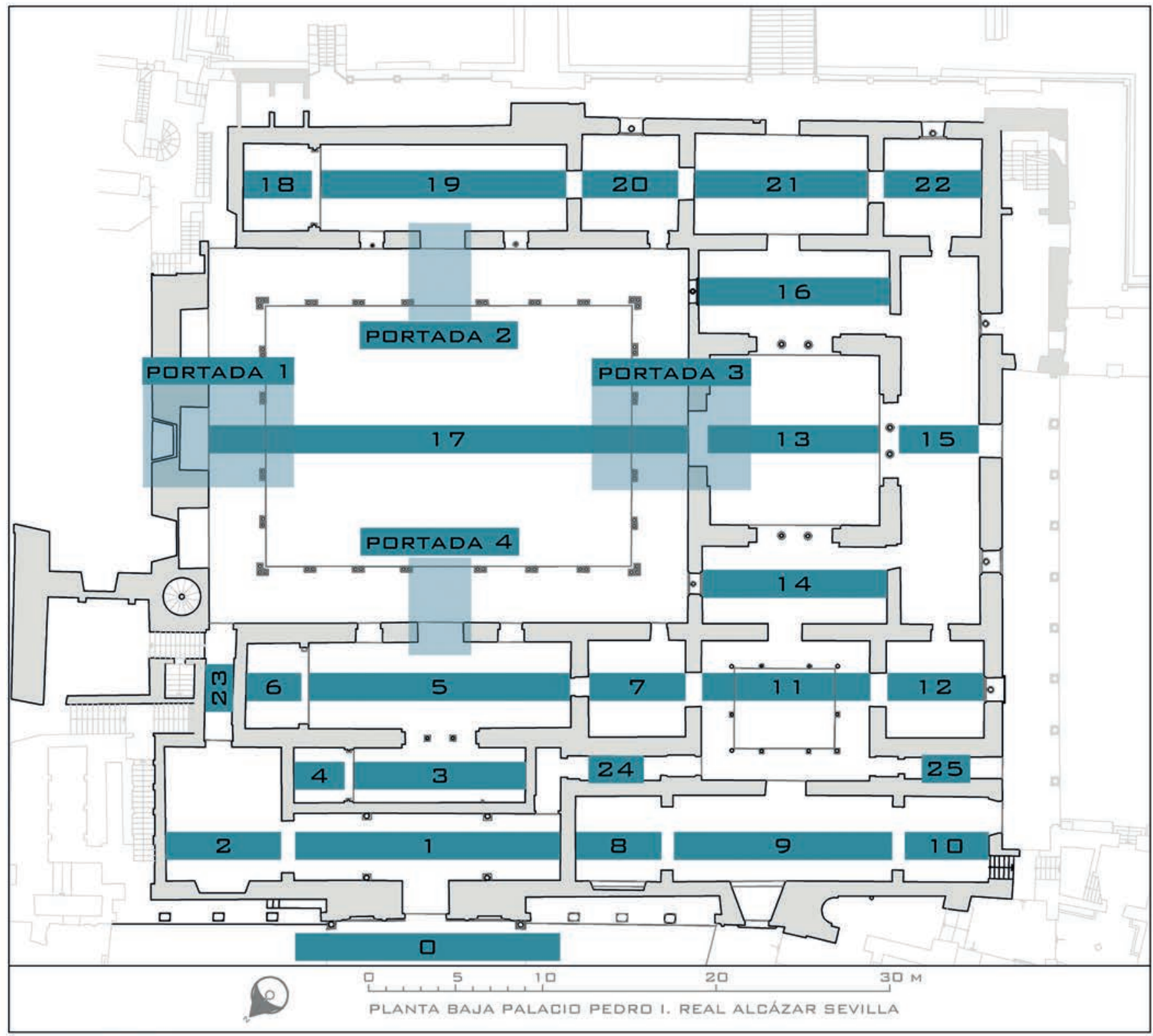

\section{DESCRIPCIÓN ÁREAS}

$\begin{array}{ll}\text { ÁREA 0: } & \text { P. MONTERIA Y FACHADA } \\ \text { ÁREA 1: } & \text { VESTIBBULO } \\ \text { ÁREA 2: } & \text { VESTÍBULO } \\ \text { ÁREA } 3 \text { Y 4: } & \text { DORMITORIO REYES MOROS } \\ \text { ÁREA } 5 \text { Y 6: } & \text { CÁMARA REGIA } \\ \text { ÁREA 7: } & \text { SALA DE LOS PASOS PERDIDOS } \\ \text { ÁREA 8-10: } & \text { CUARTO DEL PRÍNCIPE } \\ \text { ÁREA 11: } & \text { PATIO DE LAS MUÑECAS }\end{array}$

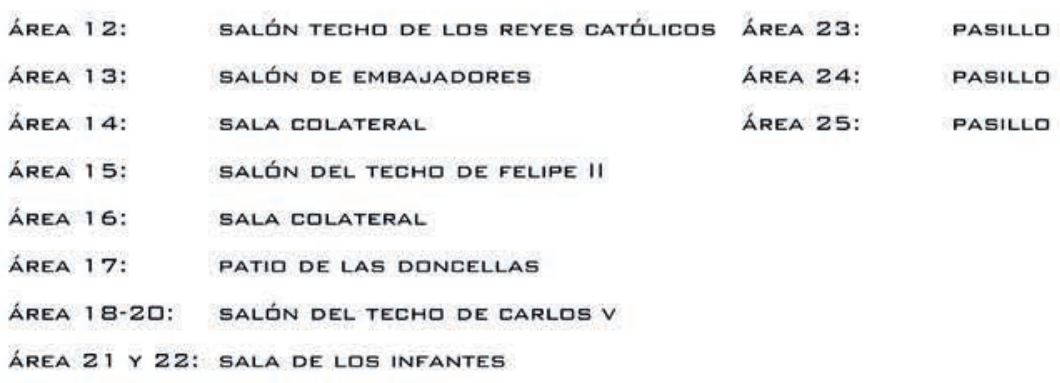

Figura 1. Plano de codificación de estancias y ubicación de las cuatro portadas principales de acceso desde el Patio de las Doncellas al resto del palacio. Plano modificado a partir del levantamiento realizado por el Dr. Antonio Almagro en la Escuela de Estudios Árabes de Granada. 
En el uso de los métodos ópticos como medio de cálculo de la temperatura de un cuerpo por radiación, se cuenta con la ventaja de evitar el contacto entre el equipo y el material a estudiar, con lo que se trata de un medio no invasivo (González 2006) ${ }^{5}$. La termografía infrarroja es la técnica que produce una imagen visible que capta la radiación infrarroja invisible para el ojo humano que es emitida por los cuerpos (Astarita 2006 citado por González 2006) ${ }^{6}$. A través de esta técnica se pueden observar las discontinuidades térmicas existentes, que se deben a cambios de densidad y calor específico (inercia térmica), de forma que, por ejemplo, la piedra tendrá una mayor capacidad de almacenar energía y tardará más tiempo en enfriarse o calentarse, mientras que el cemento lo hará de forma más rápida (Lerma, Mas, Gil, Vercher y Peñalver 2013). Mediante este procedimiento se pueden observar discontinuidades, tipos de materiales, así como los problemas relacionados con la ascensión capilar, lluvia, higroscopicidad y condensaciones en el interior de los paramentos.

En la planta baja del palacio de Pedro I se ha realizado una termografía de tipo pasivo sin activación de procesos (Gómez-Heras 2012), teniendo en cuenta que la emisividad registrada puede variar según el tipo de material, la geometría, tipo de superficie (las lisas y pulidas emiten una mayor cantidad), ángulo de toma de la imagen para evitar reflejos y la temperatura ambiente (Zahonero 2015) 7 . Las tomas se han realizado mediante una cámara termográfica FLIR modelo T440 con las siguientes características principales ${ }^{8}$ :

- Resolución de IR: 76800 (320 x 240) píxeles.

- Rango de temperaturas: entre $-20^{\circ} \mathrm{C}$ y $1200{ }^{\circ} \mathrm{C}$.

- Campo de visión: $25^{\circ} \times 19^{\circ}$.

- Sensibilidad térmica: $<0,045^{\circ} \mathrm{C}$ a $30^{\circ} \mathrm{C}$.

- Rango espectral: 7,5 a $13 \mu \mathrm{m}$.

Hay que puntualizar que en el caso del estudio realizado en el palacio de Pedro I se han detectado ciertas

\footnotetext{
5 González Fernández, D. A. 2006: Contribuciones a las técnicas no destructivas para evaluación y prueba de procesos y materiales basadas en radiaciones infrarrojas. Tesis doctoral inédita. Universidad de Cantabria, Santander.

6 Ídem.

7 Zahonero Simó, J. 2015: Evaluación de la idoneidad de la termografía y el georradar para caracterizar materiales de construcción. Trabajo Fin de Máster. Universitat politécnica de València, Valencia.

8 Ficha técnica Flir T440 [en línea] http://www.flir.com/uploadedFiles/ Thermography_USA/Products/Product_Literature/flir-t420-t440-datasheet. pdf [consultado el 01/04/2017].
}

variaciones en las imágenes termográficas registradas en una misma zona dependiendo del periodo estacional en el que han sido tomadas.

\section{LA FACHADA PRINCIPAL $Y$ VESTÍBULOS DEL PALACIO DE PEDRO I}

La investigación que se ha llevado a cabo en los vestíbulos de entrada del palacio de Pedro I, Áreas 1 y 2 de acuerdo con nuestra codificación, están profundamente relacionadas con lo que se lleva a cabo en la fachada del mismo, Área 0 de nuestra codificación. La construcción del palacio de Pedro I entre 1364 y 1366 incluyó una portada que se aleja de los principios de intimidad propios de la cultura islámica de la que toma ciertos elementos, pero que se desarrolla hacia otros niveles de comprensión y vinculación con la sociedad que ahora ocupa Sevilla, quedando esta zona hacia el Patio de la Montería como un lugar que se relaciona con lo público a través de la qubba del piso alto que destacaría sobre el resto en la parte superior de la fachada (Almagro 2015a).

\section{Intervenciones en la fachada principal referentes a los vestíbulos de acceso}

La fachada principal del palacio de Pedro I se compone de un cuerpo central y dos laterales orientados al norte. El cuerpo central o portada está también dividida en tres partes, con sus extremos simétricos y compuestos en su parte baja por un arco lobulado sobre el que se sitúan paños de sebka, quedando la zona central para la ubicación de la puerta principal de tipo rectangular con dovelas que se encuentran profusamente decoradas de ataurique (Almagro 2009b). Sobre la fachada del palacio de Pedro I, que ha sido estudiada extensamente, nos interesa lo relacionado con la apertura de vanos en la planta baja ya que afectan a la estructura y articulación de los vestíbulos con el exterior y el interior del palacio. Nos han interesado, por lo tanto, las intervenciones realizadas por Manuel Zintora en 1806 según la descripción de Don Miguel de Olivares, arquitecto de la nueva catedral de Cádiz, en su informe de reconocimiento del Alcázar a petición de D. Francisco Bruna, en el que especifica la apertura de ventanas en el cuerpo bajo, dos de mayores dimensiones y otras dos pequeñas pegadas al cuerpo central, que modificarán los vestíbulos de entrada 
(Chávez 2004)9. Sobre estas actuaciones se pronunciará Manuel Zintora en 1810, aduciendo los motivos por los que fue intervenida, ya que se encontraba en mal estado por el tiempo y la necesidad de incluir las ventanas como medio para introducir luz en los salones a la vez que aportaba elementos de simetría en la fachada (Gestoso 1889), estos vanos se cerraron en 1936 (Almagro 2009b). La distribución de los huecos de la fachada abiertos a principios de siglo ha quedado reflejada en un dibujo de Chapuy (Fig. 2) ${ }^{10} 1844$.

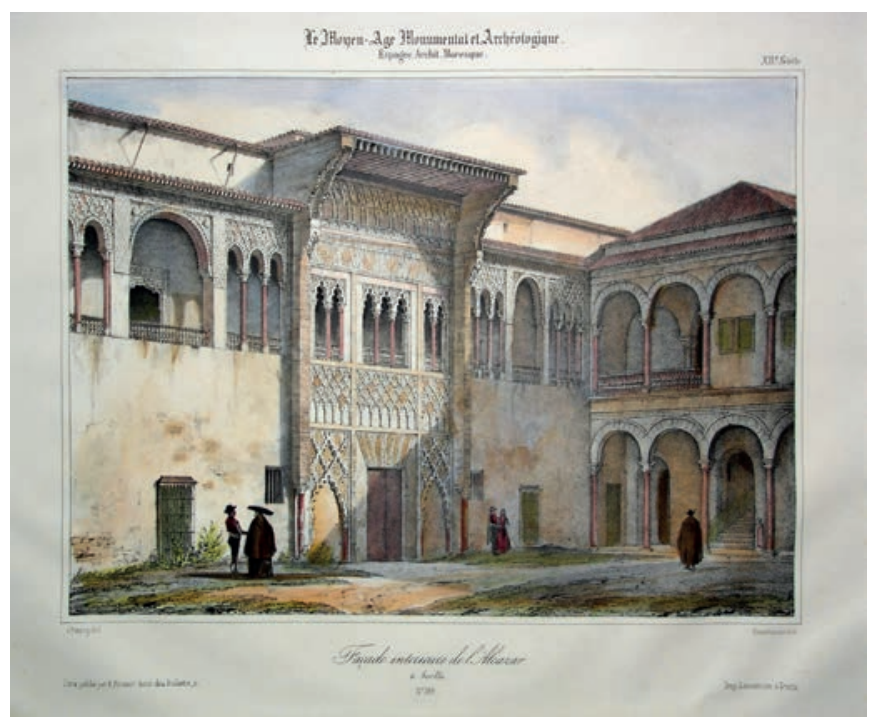

Figura 2. Dibujo de la fachada principal del palacio de Pedro I del Real Alcázar de Sevilla realizada por Chapuy (1844). Colección Laurence Shand, Sevilla.

A lo largo del siglo XIX se sucederán en la fachada otras intervenciones, como las realizadas por Juan Manuel Caballero en 1845 referentes a las cornisas, o las realizadas en 1847 en las galerías superiores (Chávez 2004). En 1848, Valentín Carderera, propondría una serie de cambios en la fachada que explica en un dibujo

\footnotetext{
9 Estos vanos ya aparecían dibujados en planos previos, como el de Vermondo Resta de 1608 (Marín 1990), que consideramos de proyecto y del que no se conocen las obras que se llegaron a concluir. Ya en el siglo XVIII se encuentra el plano realizado por Sebastian van der Borcht en 1759 (Chávez 2004) del que existen tres versiones, la primera de las cuales se encuentra firmada por el autor. En esta planimetría no aparecen las ventanas al Patio de la Montería, por lo que no se debieron abrir en el siglo XVII según lo que se recoge en el plano de Vermondo Resta. De dicho plano existen dos copias, una en la que no aparecen estas ventanas y una segunda en la que se puede apreciar que las ventanas están dibujadas a posteriori con el fin de actualizarlo a la actualidad que presentaría tras la intervención de principios del siglo XIX de Manuel Zintora.

10 Chapuy 1844. Façade interieure del L'Alcazar á Seville [en línea] http:// www.grabadoslaurenceshand.com/vista-del-alcazar-de-sevilla-del-siglo-xix/ [consultado el 25/04/2017].
}

(Fig. 3) ${ }^{11}$, que une a otros que muestran el estado de la fachada en ese momento, en el que se observan los huecos de menores dimensiones a ambos lados de la portada y otros dos en los extremos (Fig. 4) ${ }^{12}$ (Chávez 2004).

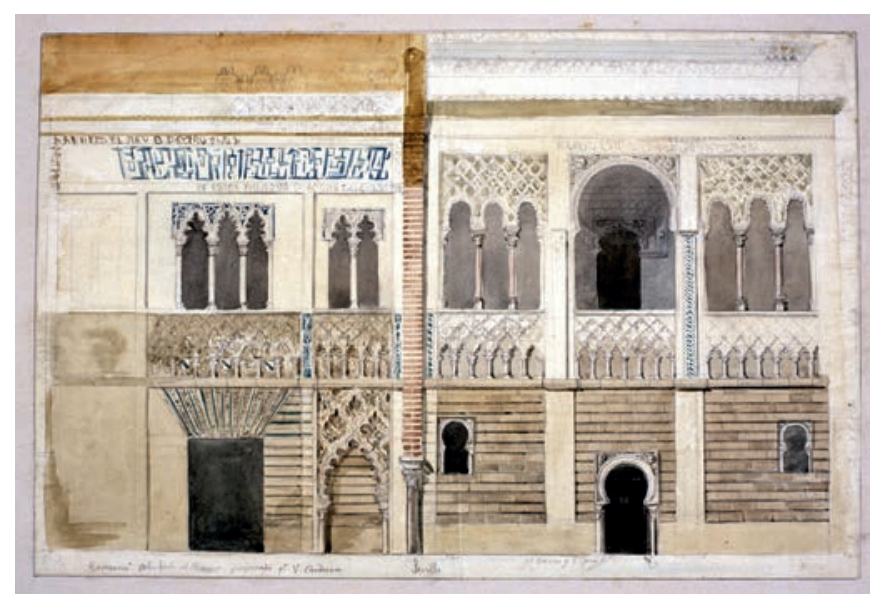

Figura 3. Propuesta de Carderera para la modificación de la fachada del palacio de Pedro I.

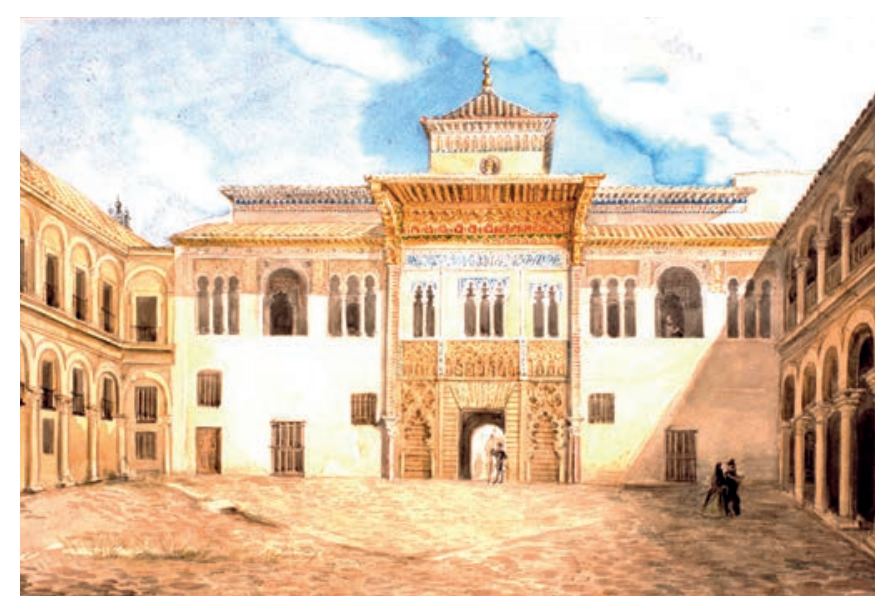

Figura 4. Dibujo de Valentín Carderera sobre el estado del Patio de la Montería.

Una de las primeras fotografías de la fachada del palacio fue la realizada por Tenison en 1853 (Fig. 5) ${ }^{13}$, en ella se observaban los huecos realizados en la primera mitad

\footnotetext{
11 Carderera 1848. Proyecto de restauración de la fachada [Dibujo]. CMuseo Lázaro Galdiano. CER.es (http://ceres.mcu.es), Ministerio de Educación Cultura y Deporte. Recuperado de http://ceres.mcu.es/pages/Viewer?accion=4\& AMuseo=MLGM\&Ninv=09494 [consultado el 06/04/2014].

12 Carderera 1848. Patio de la Montería, Fachada. [Ilustración]. CMuseo Lázaro Galdiano. CER.es (http://ceres.mcu.es), CMinisterio de Educación Cultura y Deporte. Recuperado de http://ceres.mcu.es/pages/Viewer?accion= 4\&AMuseo=MLGM\&Ninv=09725 [consultado el 06/04/2014].

13 Tenison 1853. Puerta del perdón. Alcázar de Sevilla [Fotografía] [en línea] http://coleccionfff.unav.es/bvunav/i18n/consulta/registro. cmd?id=3240 [consultado el 26/03/2014].
} 
del siglo XIX por Zintora, que produjeron un cambio en la estética de la fachada y evidencia que todavía no se habían llevado a cabo las intervenciones propuestas por Carderera unos años antes. Dicha intervención de armonización de los laterales, se realizaría a mitad del siglo XIX por José de la Coba, entre 1854 y 1857, dado que en la fotografía de 1853 todavía aparecen los huecos abiertos a principios de siglo y, sin embargo, no están los revestimientos laterales que sí se pueden observar tanto en el dibujo realizado por Guichot años antes, seguramente copiado del proyecto de Carderera (Fig. 6) ${ }^{14}$ como en diversas fotografías como la de Pedrosa de 1857, en la que ya sí aparece este diseño previo (Fig. 7) ${ }^{15}$.

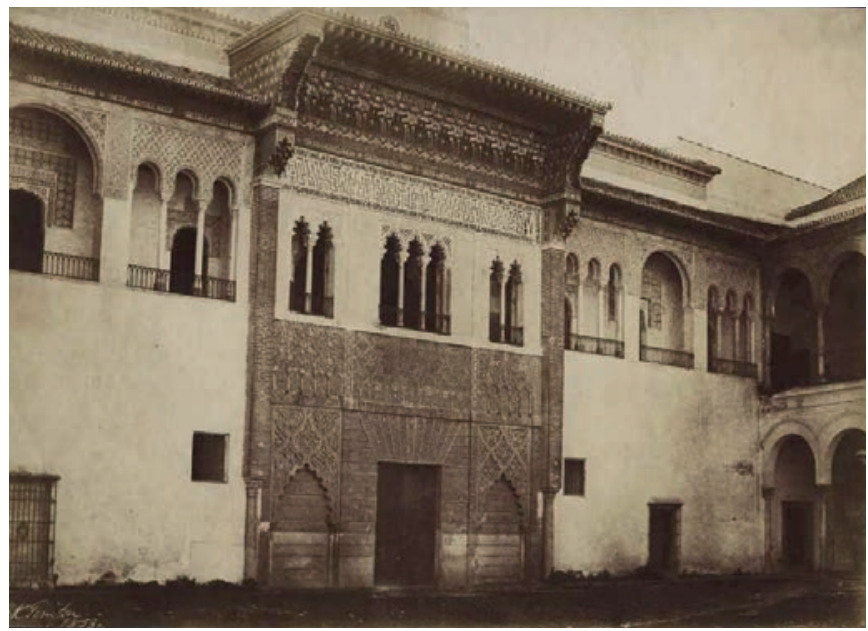

Figura 5. Portada principal del Alcázar. Fotografía tomada por Tenison.

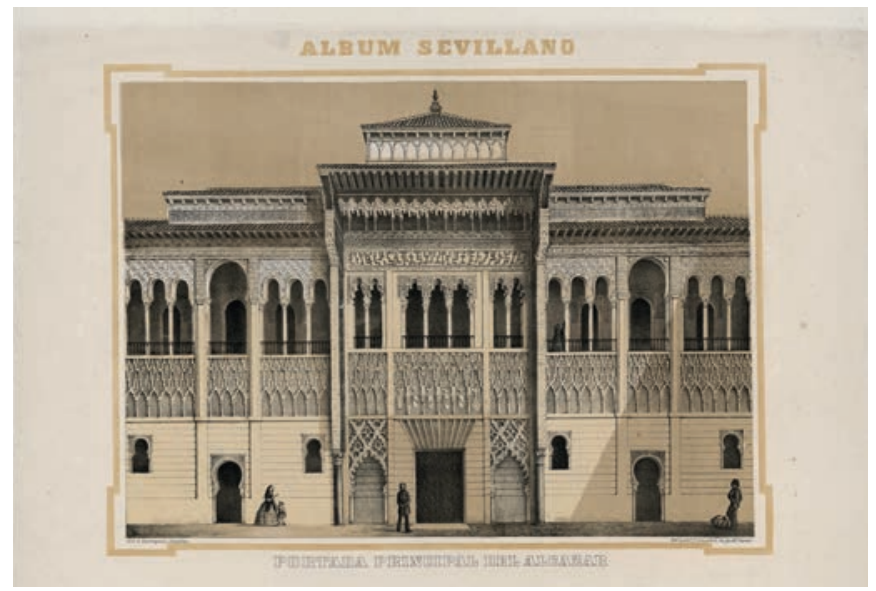

Figura 6. Fachada principal del Alcázar realizada por Guichot.

\footnotetext{
14 Guichot 1850-1852. Portada principal del Alcázar Dib. Y litografía J. Guichot [sic]; las fig. dibujo Chaman [Ilustración] [en línea] http://bdh-rd. bne.es/viewer.vm?id=0000066990 [consultado el 30/03/2014].

15 Pedrosa 1857. Sevilla. Portada del Alcázar [Fotografía] [en línea] http:// www.alhambra-patronato.es/ria/handle/10514/10386 26/03/2014 [consultado el 30/04/2014].
}

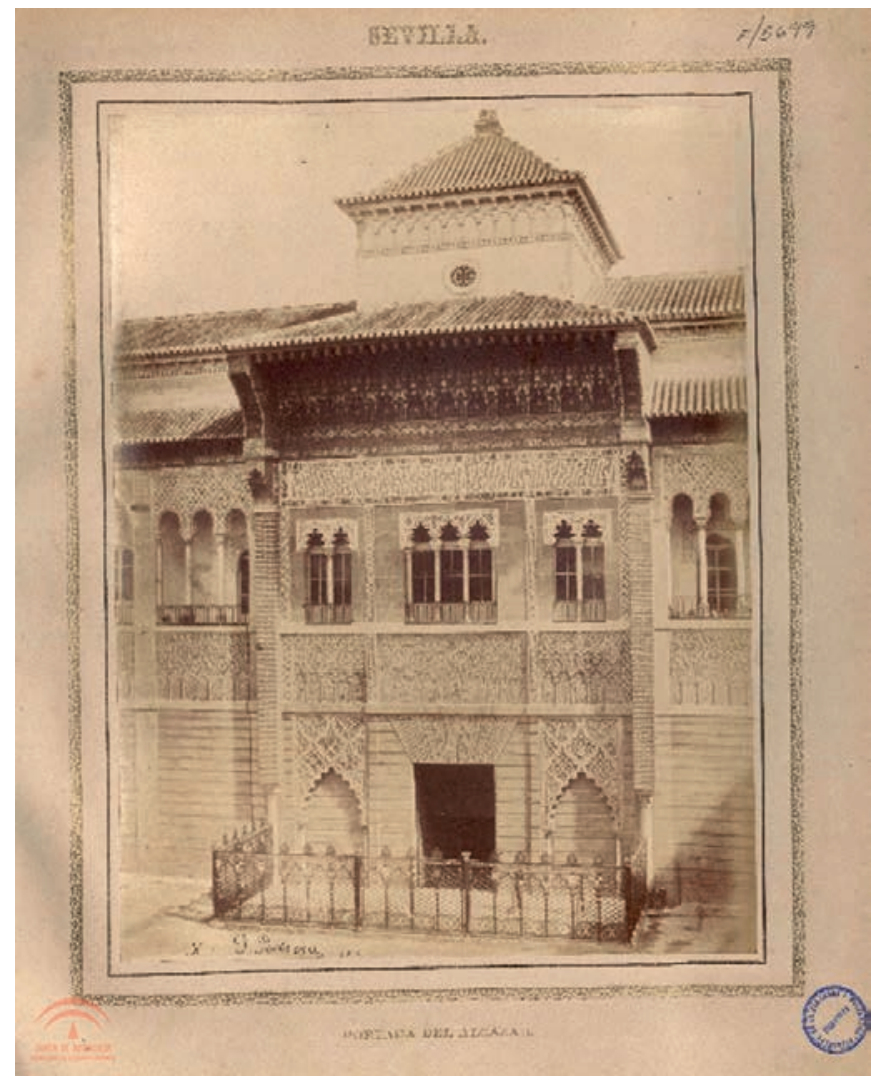

Figura 7. Fachada principal del Alcázar. Fotografía de Pedrosa.

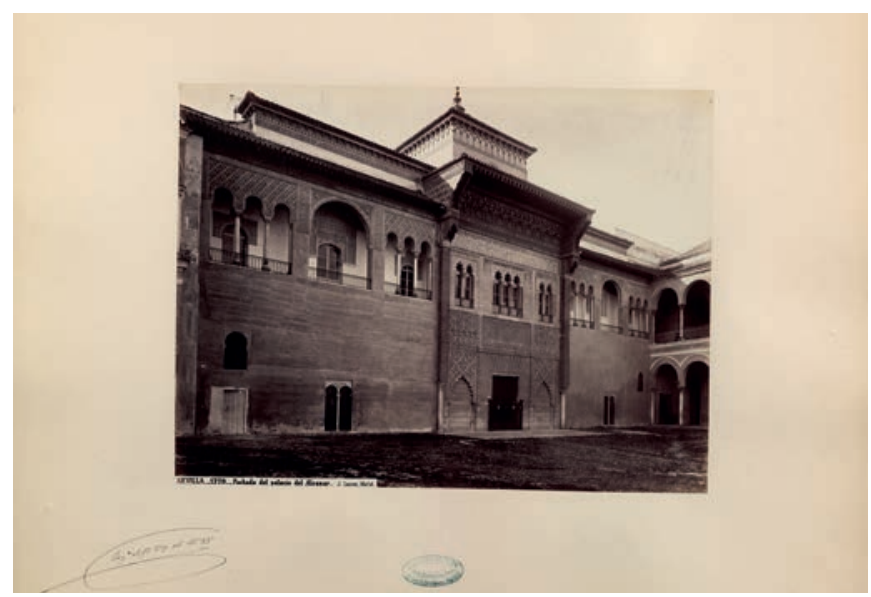

Figura 8. Fachada principal del palacio de D. Pedro en el Alcázar de Sevilla.

La reforma realizada en los laterales según la traza de Carderera debió desaparecer poco antes de 1870, año en que la Biblioteca Nacional de España fecha la imagen que toma Laurent de la fachada (Fig. 8) ${ }^{16}$ en la que ya no encontramos este revestimiento y que Almagro (2009b) data de unos años más tarde, 1874.

16 Laurent 1870. Sevilla, fachada del palacio del Alcázar. J. Laurent. Madrid [Fotografía] [en línea] http://bdh-rd.bne.es/viewer.vm?id=0000019429 [consultado el 04/04/2014]. 
Continuando con las referencias escritas, contamos con la descripción en 1889 por parte de Gestoso (1889) que menciona la existencia de una puerta en la parte izquierda como acceso a la escalera de la segunda planta, a la que inicialmente se accedería a través de la zona izquierda del vestíbulo de entrada. En 1900 (Chávez 2004) se estarían llevando a cabo diversas actuaciones que dan lugar a un descubrimiento en esta fachada, apareciendo la primitiva arcada mudéjar que flanqueaba la fachada y que ya se observaba en una postal del fotógrafo Rafael Señán y González, que debió ser tomada a principios del siglo XX, donde aparecen los revestimientos picados de los laterales y las arcadas cegadas (Fig. 9) ${ }^{17}$.

17 Señán y González 1905. 96-Sevilla-Puerta de entrada al Alcázar. [Fotografía postal]. Colección particular Alfonso Jiménez.
Las arcadas de la fachada serían revestidas de nuevo a principios de siglo como se puede observar en la fotografía tomada por Garzón, recogida en el Catálogo Monumental de España en su volumen 1, datado en 1907 (Fig. $10)^{18}$, donde se observa la transformación de las ventanas geminadas que se encontraban en el centro de los laterales por otras rectangulares con rejas, cerrando también los huecos presentes en los laterales de la zona central que sí aparecían a principios de siglo en la imagen tomada por Señán cuando se realiza el picado de la superficie (Fig. 9).

\footnotetext{
18 Garzón 1907. Fachada principal. Sevilla Alcázar [Fotografía]. Fernández Casanova, A. 1907: Catálogo Monumental de España Provincia de Sevilla, Tomo I, Lámina 72. Ministerio de Instrucción Pública y Bellas Artes, Madrid [en línea] http://aleph.csic.es/F?func=find-c\&ccl_term=SYS\%3D001359510\&local_ base=MAD01 [consultado el 01/06/2017].
}

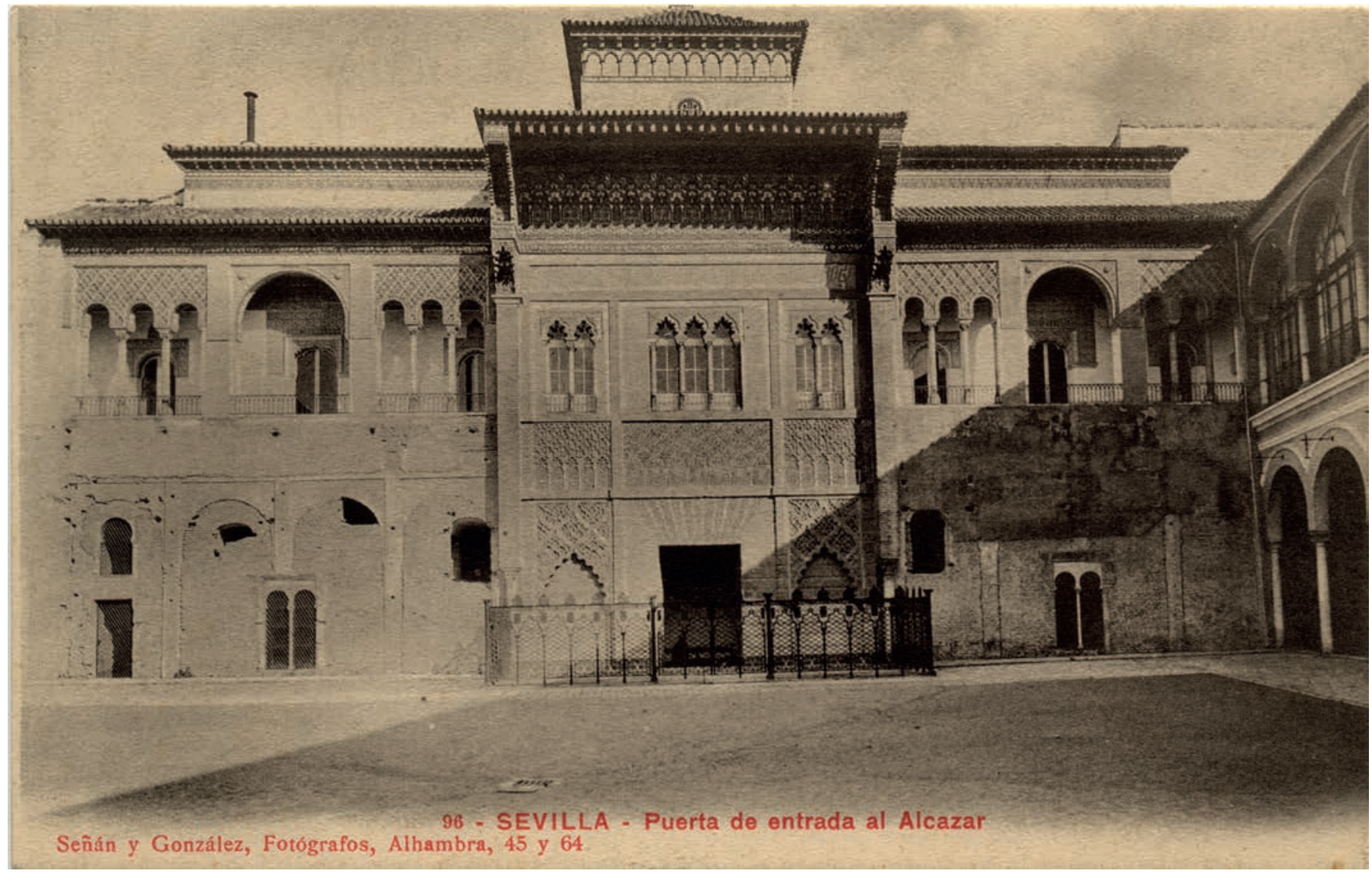

Figura 9. Fachada principal del palacio de Pedro I. Fotografía realizada por Rafael Señán y González. Colección particular de Alfonso Jiménez. 


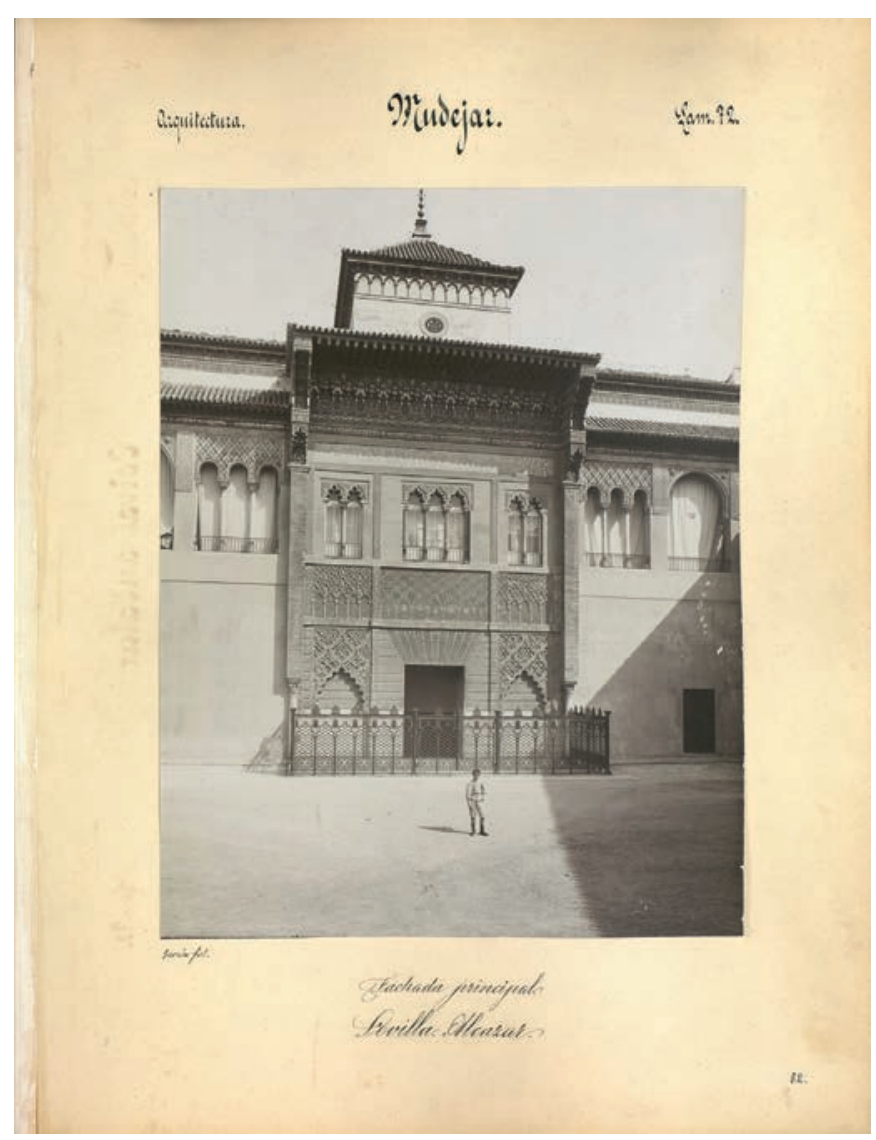

Figura 10. Fachada principal del Alcázar de Sevilla. Fotografía de Catálogo Monumental de España.

\section{Intervenciones en los vestíbulos del palacio}

Entrando a través de la puerta principal, ya en la zona interior del palacio, se encuentra un primer vestíbulo que en su zona derecha da paso a uno de los patios, el Patio de las Muñecas, y a la izquierda al segundo vestíbulo en el que se ubica la puerta del corredor que se dirige al Patio de las Doncellas (Fig. 11). Los vestíbulos, como espacios previos al resto de estancias, tienen, en el caso del primer vestíbulo, forma alargada con una división tripartita mediante unos arcos que descansan sobre columnas de mármol. Cada uno de sus muros se encuentra dividido a su vez en franjas de decoración, de forma muy similar a todo el palacio, contando en la zona inferior con paños de alicatado, seguido de una franja de yesería, una zona sin decoración que es el espacio enlucido y a continuación otra franja de yesería de mayor tamaño. Esta estructura se ve modificada en la zona de la puerta que encontramos a la derecha que cuenta con un marco de yesería donde se ubica el mencionado acceso al corredor que se dirige hacia el Patio de las Muñecas. De la misma forma el segundo vestíbulo queda revestido con estas bandas de decoración, contando en su cara este con un arco angrelado de pequeñas dimensiones que se encuentra cegado y en la zona sur con paneles de yesería y un dintel de madera sobre el que aparecen unas dovelas alternas con decoración y lisas que decoran la puerta de paso al corredor que conduce al Patio de las Doncellas.

Sobre las intervenciones que se realizan en los vestíbulos nos centraremos en la apertura de los huecos de la fachada descritos previamente y en el acceso directo que Manuel Zintora abre entre 1805 y 1806 hasta el Patio de las Doncellas (Chávez 2004) ${ }^{19}$. Por lo tanto, en el Área 1 o primer vestíbulo se realizará la apertura de dos ventanas hacia el Patio de la Montería en su cara norte y un acceso directo hacia el Patio de las Doncellas en su lado sur. Este último es mencionado por José Amador de los Ríos (1844) en su descripción sobre la entrada al Alcázar, recogiendo la apertura de la puerta moderna que en $1806 \mathrm{se}$ abriría para dar paso de forma directa desde dicha entrada al Patio de las Doncellas. Dicha apertura dio lugar a cuatro piezas que se abren en las estancias del Dormitorio de los Reyes Moros (Área 3 y 4) y la Cámara Regia (Área 5 y 6). Alrededor de 1856 se ciega la comunicación abierta por Zintora, posteriormente al escrito en que Madrazo habla de ella describiéndola como un arco acanalado que se sostiene "por columnas de basas poco menos que áticas y capiteles de líneas" (Madrazo 1856: 476), mencionando también las salas que quedan a derecha e izquierda, las cuales se encuentran en su mayoría sin decoración, observándose al fondo el Patio de las Doncellas.

Conociendo estos datos se ha realizado el estudio termográfico en el vestíbulo (Área 1) mediante el que se ha comprobado la existencia de zonas de forma rectangular y con una temperatura inferior respecto a las zonas limítrofes, lo que indica la presencia de huecos que están ahora tapiados, que se supone fueron ventanas a la fachada y puerta hacia el Patio de las Doncellas. En el caso de las ventanas abiertas en la fachada a principios del siglo XIX por parte de Manuel Zintora, debieron

\footnotetext{
19 Algunos autores consideran la apertura del acceso directo desde la fachada del palacio hacia el Patio de las Doncellas anterior a la realizada por Manuel Zintora. Estas hipótesis se basan en los planos ya mencionados como el realizado por Vermondo Resta en 1608 (Marín 1990) y el posterior de Sebastian van der Borcht de 1759, que consideramos de proyecto. Marín (2006) también menciona un documento en el que se recogían las obras a realizar, entre las que se incluye la rehabilitación de una puerta que sale al Patio desde el vestíbulo de entrada, que Marín (2006) define como el primero pero que es definido en dicho documento con tabiques, por lo que debe referirse al segundo en el que se encuentra el acceso actual hacia el Patio de las Doncellas.
} 

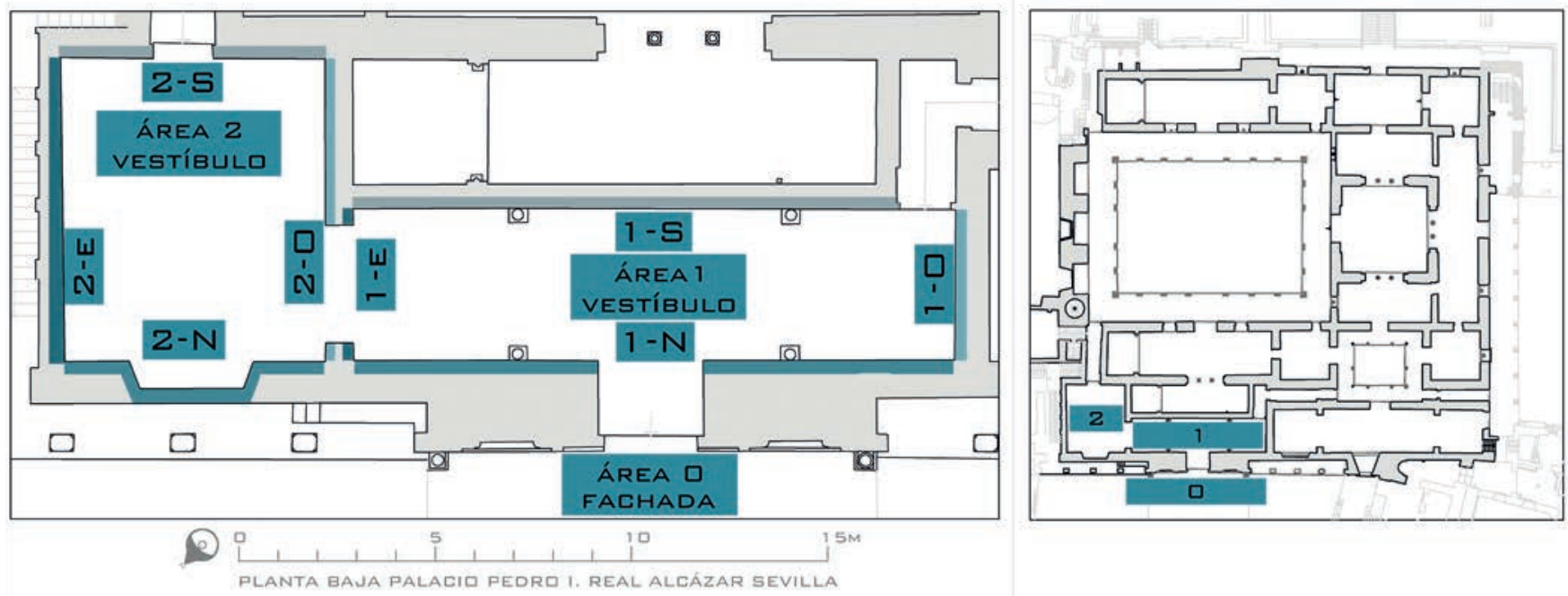

Figura 11. Plano de ubicación del área 1 y 2 del Vestíbulo y la denominación de paramentos. Plano modificado a partir del levantamiento realizado por el Dr. Antonio Almagro en la Escuela de Estudios Árabes de Granada.

tener diversas proporciones aunque siempre una ubicación más o menos similar, tal y como se puede observar en el estudio termográfico, en el que, aunque sus bordes quedan difuminados, se puede apreciar un área donde el contraste de temperaturas es mayor (Fig. 12).

Por otro lado, continuando con el estudio termográfico realizado pasamos al paramento sur del primer vestíbulo donde se ha podido observar, aunque de forma más sutil que en el caso del paramento norte, la señal del arco que daba paso al Patio de las Doncellas practicado a principios del siglo XIX (Fig. 13). El estudio de las imágenes nos permite aproximar la delineación del arco, situándolo en el centro del paramento que como se observa en la figura 13 nos dejaría ver la estancia trasera del dormitorio de los Reyes Moros, ya que todavía no contaría con el vano tripartito que se puede observar parcialmente en la imagen, pero que da una idea de la intención con que se realizó esta apertura. Con esta reforma se produce una alteración en el acceso en recodo que caracterizaba este palacio desde su construcción (Gestoso 1889) y que no se recuperaría hasta 1856 cuando José de la Coba, como menciona en sus informes, cierre el arco de medio punto y elimine la cancela de hierro que daba vista al Patio de las Doncellas (Chávez 2004).

\section{EL PATIO DE LAS DONCELLAS DEL PALACIO DE PEDRO I}

Una vez identificadas las intervenciones en los vestíbulos de entrada pasamos al estudio del patio principal, el
Patio de las Doncellas, una zona que se presenta como interlocución de espacios (Área 17, Fig. 14). El Patio de las Doncellas se vincula a través de una línea paralela a su lado más largo con el Salón de Embajadores y hacia el norte con un trazado perpendicular con el Patio de las Muñecas (Rodríguez 2011).

El Patio de las Doncellas adopta forma rectangular y cuenta con una estructura de pórticos mediante arcos polilobulados apoyados en columnas de mármol que en sus esquinas son triples y en el resto pareadas. Las albanegas quedan decoradas con yeserías romboidales (sebka) con decoración de ataurique, contando en cada uno de los lados del Patio con un arco central peraltado que rompe el alfiz superior sobre el que se sitúa una franja de yesería en la que se apoya la cornisa que vuela hacia el exterior y desde la que sigue en altura la segunda planta del palacio. La solución de Patio con pórticos perimetrales en sus cuatro lados, es una estructura que según Almagro (2007) resulta habitual en los claustros monásticos, contando también con una clara influencia andalusí con la disposición de las estancias tanto al sur como al norte del Patio con forma alargada y alhanías en sus lados. Las estancias del lado norte que se encuentran formadas por la Cámara Regia y el Dormitorio de los Reyes Moros constituirían junto con el Patio la clásica organización espacial islámica (Almagro 2007). En este estudio nos dedicaremos en exclusiva a la fachada interna del paramento oriental del Patio, basándonos en los levantamientos fotogramétricos desarrollados en la planta baja del palacio, dando lugar a una serie de ortofotos o proyecciones horizontales que permiten estudiar su morfología y estado actual, 


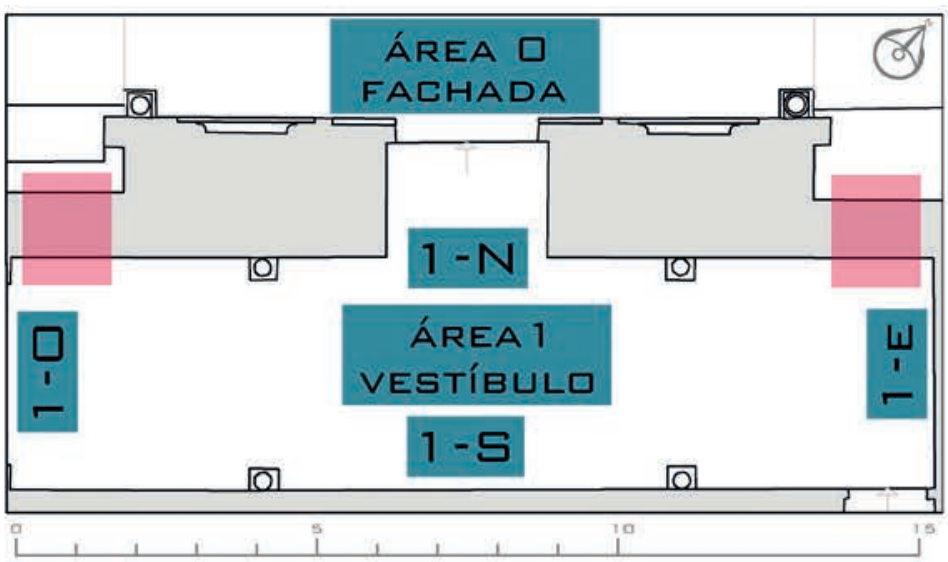

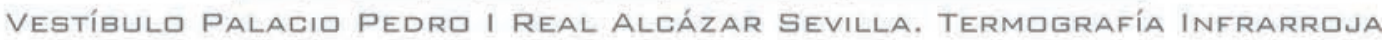
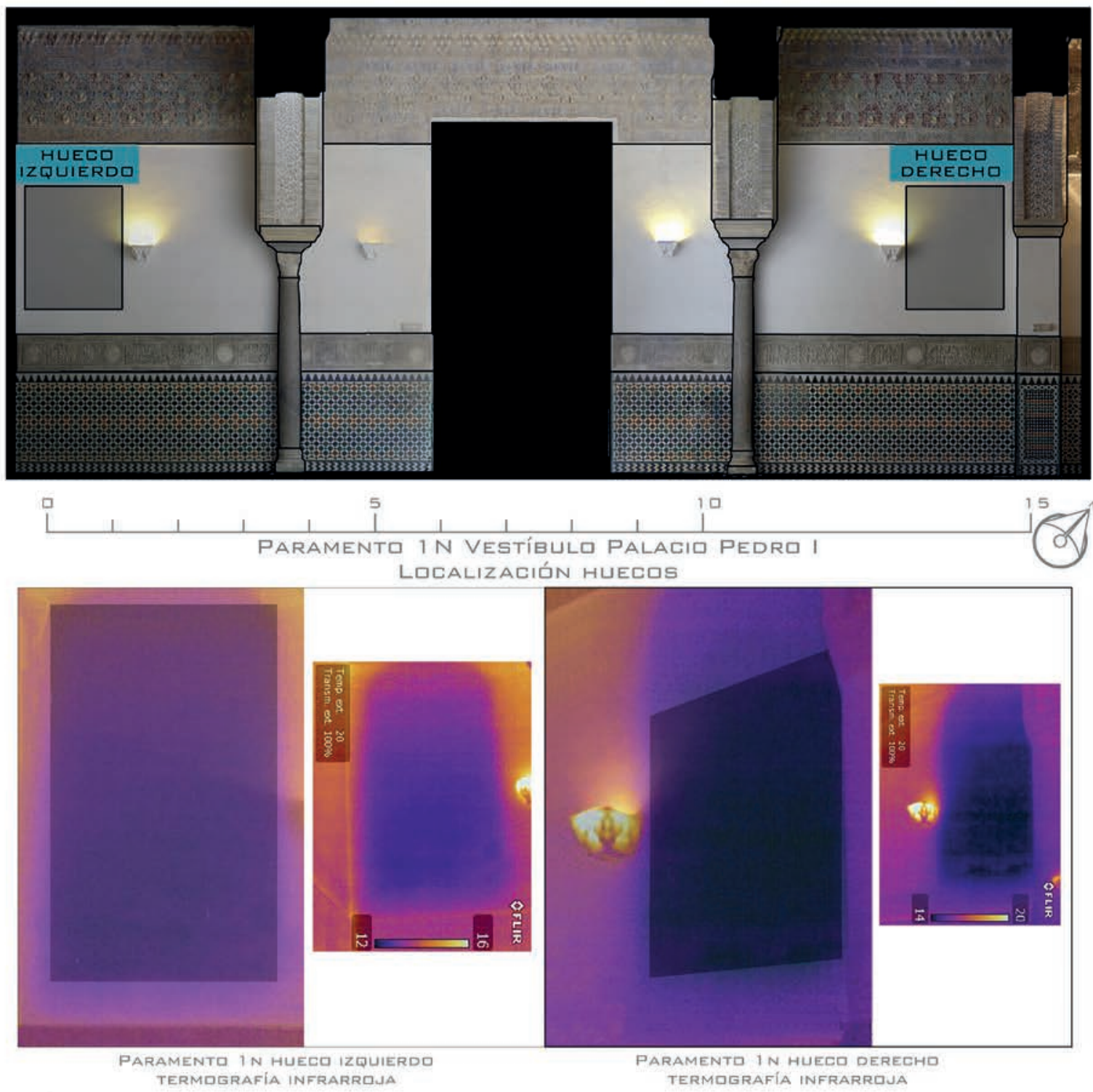

Figura 12. Zonas de estudio termográfico en el paramento $1 \mathrm{~N}$ del Vestíbulo. Palacio de Pedro I Real Alcázar de Sevilla. Ubicación de huecos practicados en la fachada del palacio a principios del siglo XIX. 


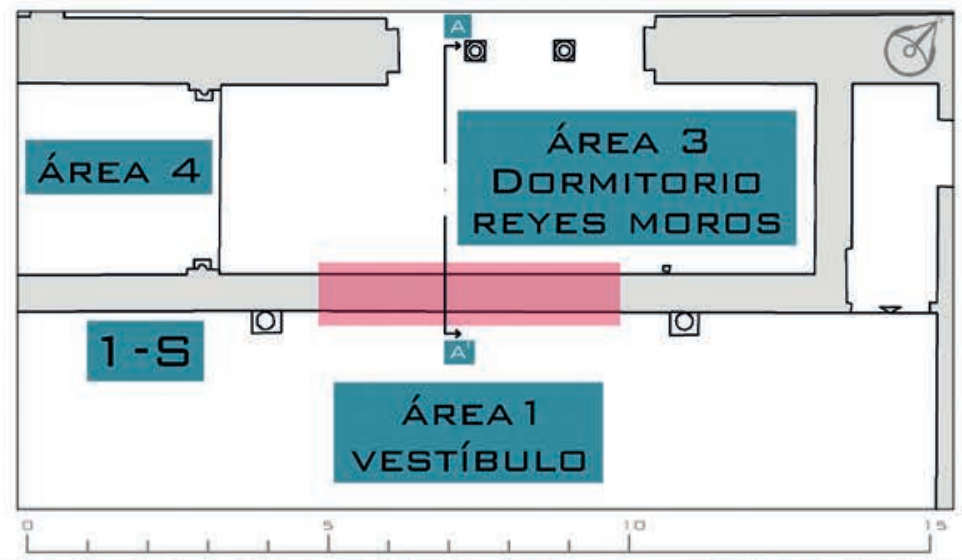

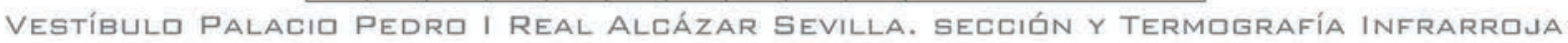
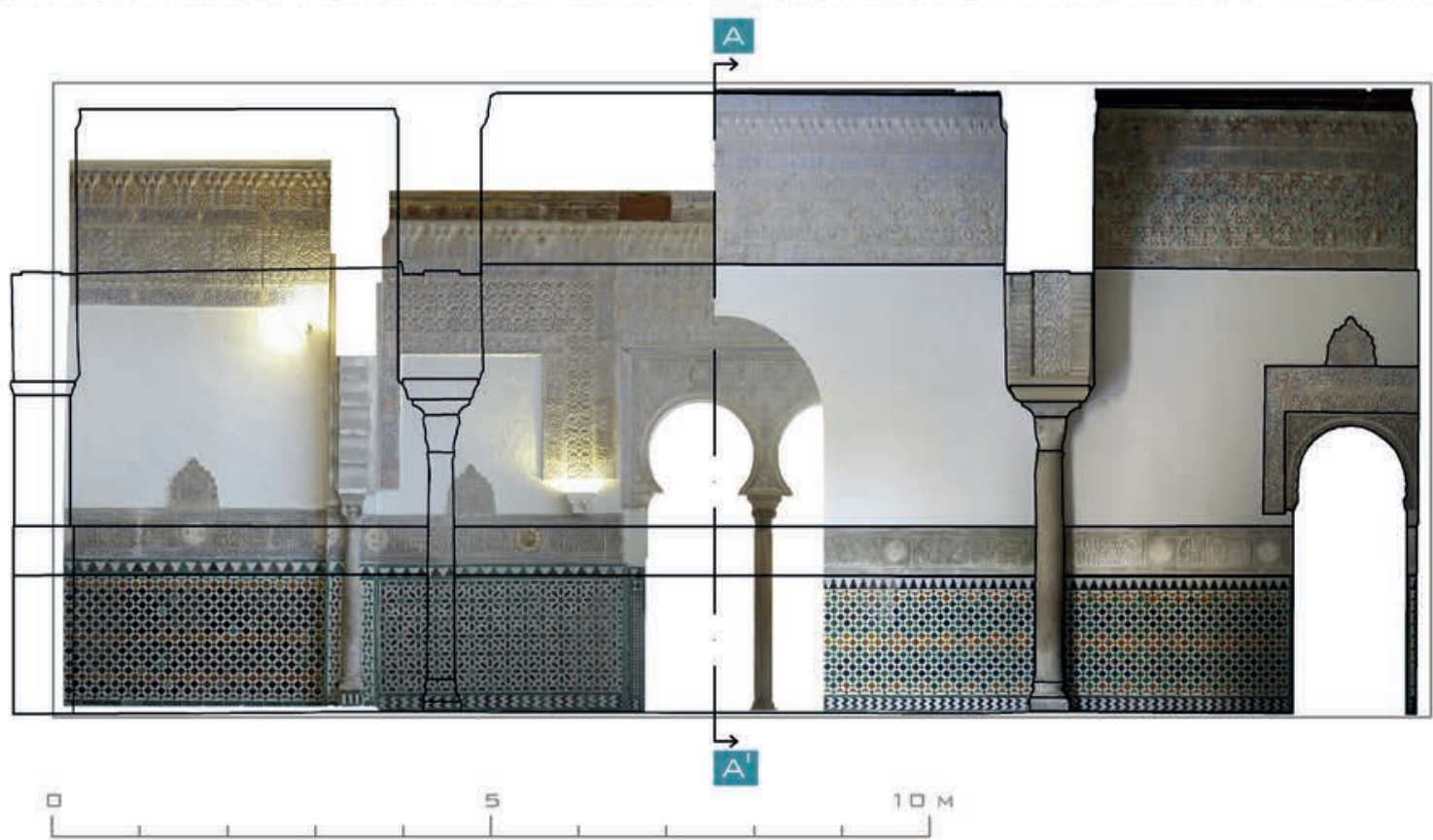

SECLIÓN A-A' PARAMENTI 1 S VESTÍBUL口 PALACIO PEDRO I REAL ALCÁzAR

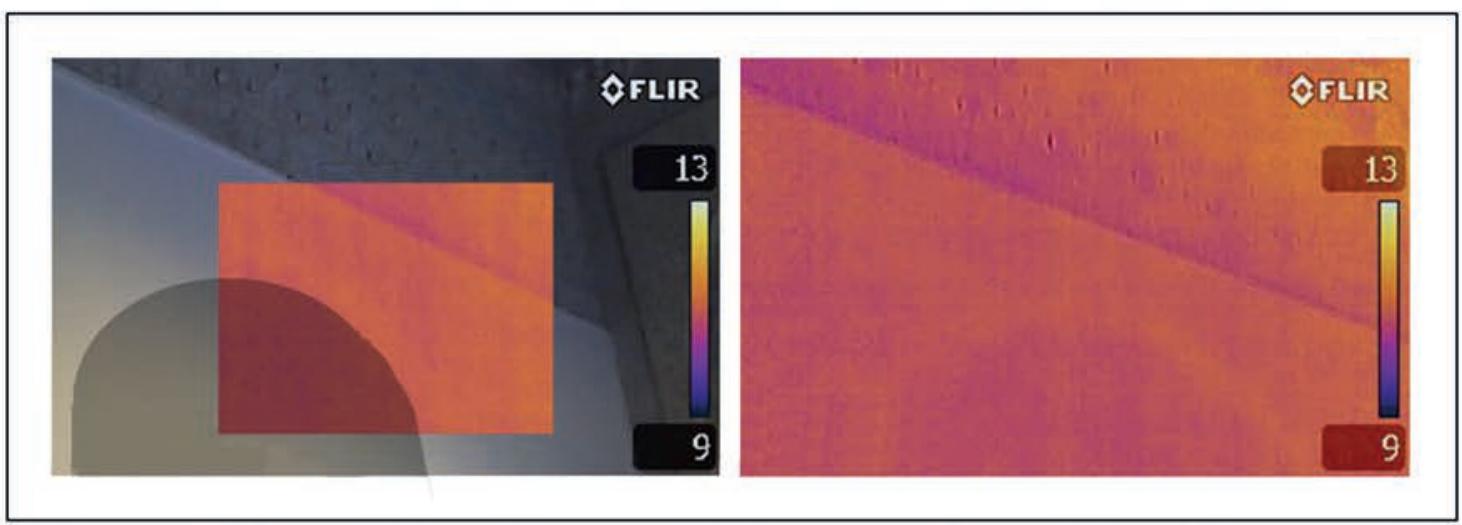

PARAMENTI 1 S PUERTA DE PASD A DONCELLAS SUPERPISICIÓN TERMOGRAFIA INFRARRIJA E IMAGEN

PARAMENTO 1 S PUERTA DE PASI A DONCELLAS IMAGEN TERMIGRÁFICA

Figura 13. Zonas de estudio termográfico en el paramento 1S del Vestíbulo. Palacio de Pedro I Real Alcázar de Sevilla. Ubicación de acceso directo practicado en el paramento en 1806. 


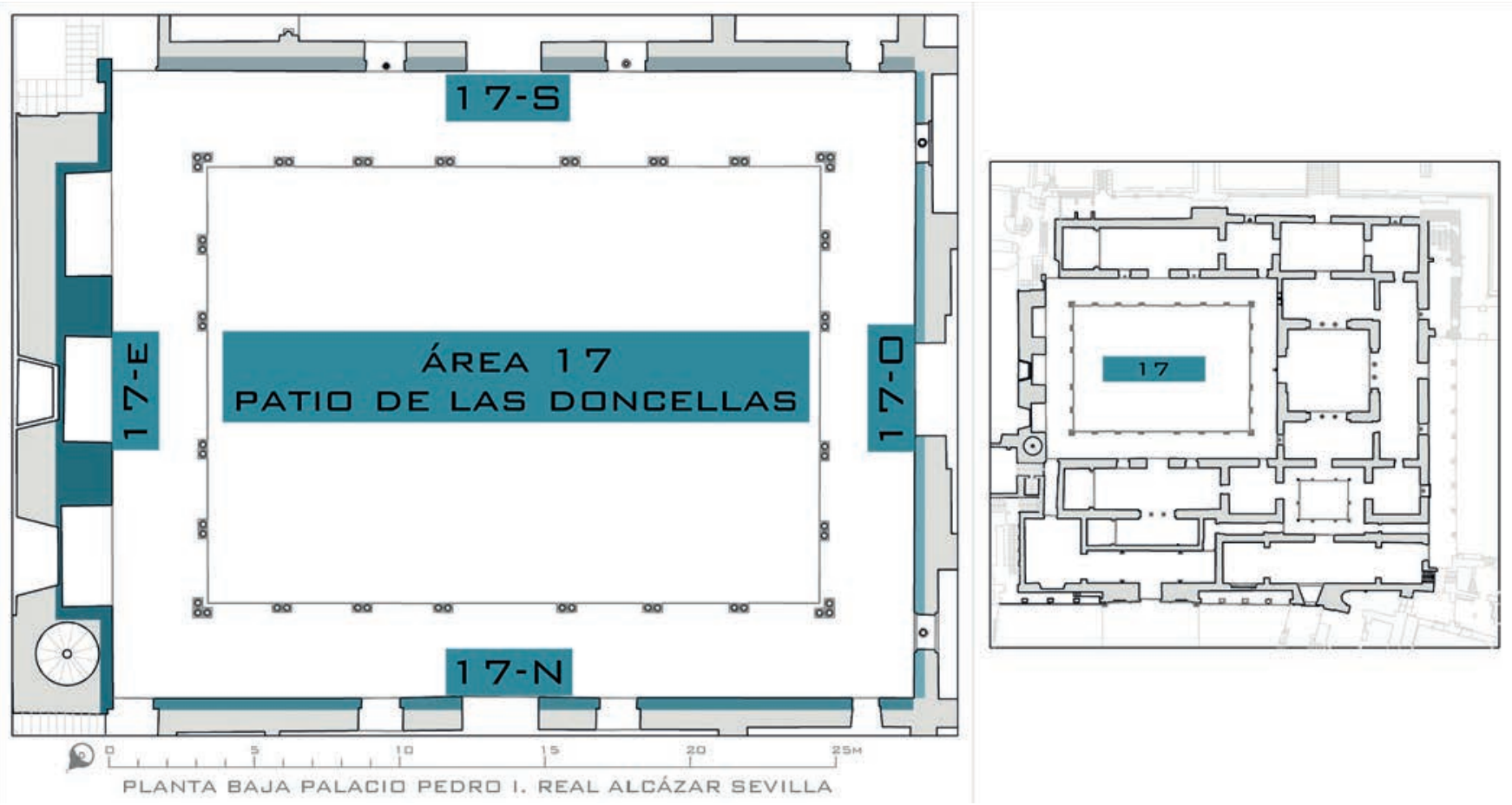

Figura 14. Plano de ubicación del área 17, Patio de las Doncellas y la denominación de paramentos. Plano modificado a partir del levantamiento realizado por el Dr. Antonio Almagro en la Escuela de Estudios Árabes de Granada.

profundizando en la historia del espacio del Patio como centro del palacio de D. Pedro (Fig. 15).

En la descripción del Patio de las Doncellas, se debe hacer mención al uso relevante del agua junto con los espacios ajardinados, que según nos precisa Almagro Vidal (2005) hace referencia al oasis y el desierto. En el proyecto inicial del palacio de D. Pedro también se le dio la debida importancia a esa unión y se valoró lo que podía aportar el jardín y el agua a la construcción, lo que quedaría demostrado por los recientes descubrimientos. Dichos descubrimientos se refieren a las investigaciones realizadas en el subsuelo (Tabales 2003), que revelan la existencia de un jardín rehundido, concebido en la construcción de la edificación, y que se distribuía de forma simétrica, situando en su eje este-oeste una alberca longitudinal con extremos en forma de $\mathrm{T}$, los cuales fueron tapados antes de llegar a estar en uso (Almagro 2015b). La disposición de este tipo de jardín con alberca longitudinal y jardín rehundido en sus laterales que no se distribuye en forma de crucero como los que lo circundan, es considerado un elemento innovador y su construcción resulta acorde con la inicial naturaleza privada de este palacio, ya que no permitiría un correcto tránsito de la corte en el espacio reducido que quedaría en los corredores (Almagro
2018). Por motivos de protocolo debió ser modificado a lo largo del siglo XVI para servir a las necesidades de la corte que era sin duda numerosa (Almagro 2015b).

\section{Intervenciones del siglo XIV y XV}

La construcción inicial de este Patio realizada entre 1364 y 1366, se compondría de arquerías sobre columnas de mármol dobles, excepto en los ángulos que se dispondría sólo una, rematadas por cimacios de madera, arcos lobulados de estilo cordobés y paños de sebka en su planta baja (Marín 1990). En época de los Reyes Católicos se realizan diversas obras de mejora en el palacio. Según las capitulaciones establecidas el 28 de septiembre de 1478 entre los Reyes Católicos y Francisco de Madrid, su secretario y obrero mayor de los Alcázares y atarazanas de Sevilla, se realizaron modificaciones necesarias para la entrada en Sevilla de Isabel I, en julio de 1477. Entre las modificaciones necesarias sólo se menciona para el Patio de las Doncellas las relacionadas con labores de sustitución de losas quebradas del pavimento, reparación de techumbres y la inspección de los tejados (Morales y Serrera 1999). 


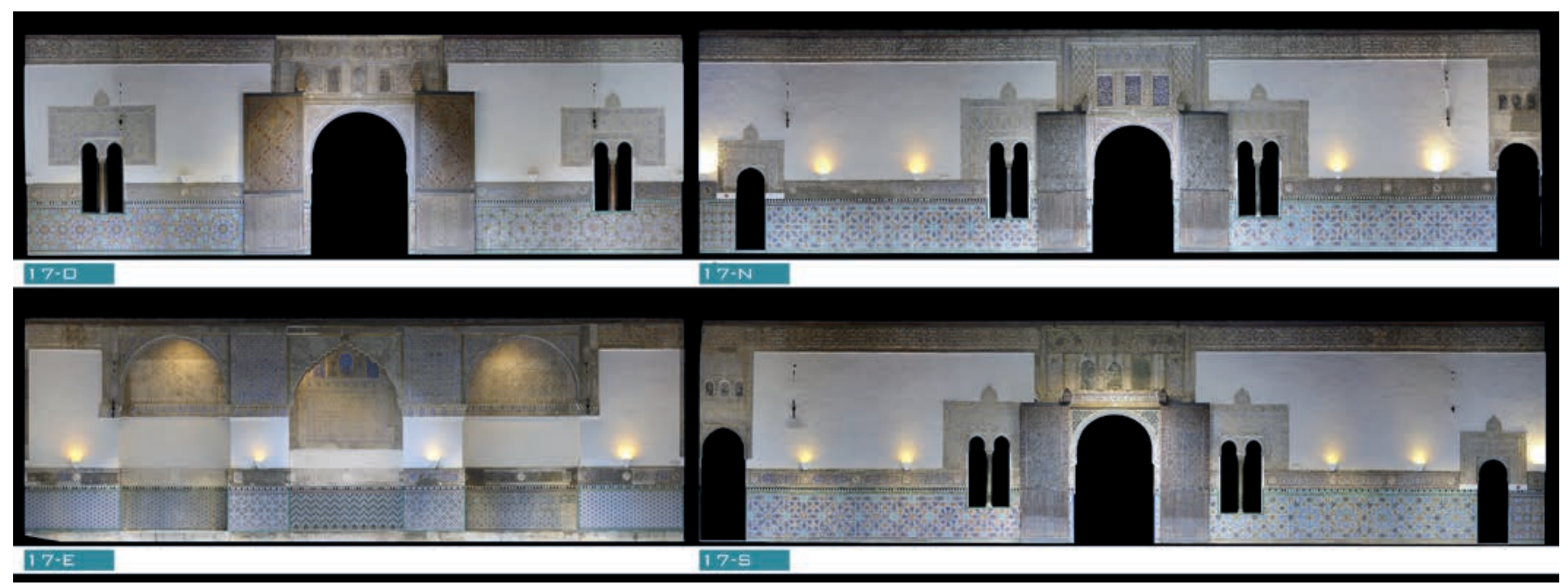

Figura 15. Ortofotos de los paramentos del Patio de las Doncellas, resultado del levantamiento fotogramétrico.

\section{Intervenciones del siglo XVI}

A lo largo de la década de 1540 con el reinado de Carlos I de España y V de Alemania, se suceden numerosos trabajos de remodelación del Patio, especialmente en los corredores altos (Marín 1990). En 1554, en época de Felipe II, según las hijuelas de este año que incluye Gestoso (1889) el alcaide D. Álvaro Manrique solicita a los maestros mayores Juan de Simancas y Juan Fernández que realicen un informe de aquellos elementos que se deben reparar en el palacio, entre los que se mencionan la mala conservación de los corredores, que deben ser apuntalados descubriendo su yesería y reparándolos y el mal estado de los pilares de albañilería a los que era necesario vaciar y meter mármol junto con capiteles.

En 1560 Felipe II solicitará una relación de los daños del Alcázar, de forma que pudiera evaluar cuánto costaría la obra a efectuar y si era realmente necesaria, por lo que D. Hernando Conchillos, alcaide de los Alcázares, manda certificar dichas necesidades a través de Juan de Simancas en 1561, enumerando una serie de obras en el Patio que se refieren a la sustitución de las cuatro columnas gruesas de cada esquina por doce a repartir tres en cada ángulo y de dieciséis columnas de las portadas para colocar soportes dobles en los arcos principales. Se explica que la eliminación de columnas fue debida a que eran de diverso tipo, más gruesas unas y otras más finas, algunas sin basas o capiteles y con cimacios de madera. Junto con esta modificación se realizaron reparaciones de albañilería, yeserías, puertas, alicatados, cañerías, suelos, incluyendo la mención a una alberca, ventanas o claraboyas de yesería de las puertas de entrada a las estancias y finalización de los enmaderamientos de los corredores altos pintándolos y dorándolos (Gestoso 1889). En relación a lo especificado sobre los zócalos de alicatado, se considera que en la parte alta de los corredores se debieron colocar en esta intervención de mediados del siglo XVI y que sin embargo en el caso de los corredores bajos serían originales de la construcción del palacio, ya que se especifica que se deben reparar y no construir dichos alicatados, como ya apuntaba Pleguezuelo (2015) considerando su complejidad en los motivos de las fachadas norte, sur y oeste del Patio.

A lo largo de la década de 1560 a 1570 se suceden diversas intervenciones en las yeserías y techumbres, como recogen los maestros mayores Juan Fernández y Juan Simancas y el veedor Alonso de Rojas, que especifican labores referidas a las galerías altas y a la talla de yeserías de los arcos centrales (Marín 1990).

Las obras en el Patio de las Doncellas se darían por terminadas en 1584, siendo en los últimos años del reinado de Felipe II, entre 1581 y 1584, cuando se llevan a cabo las últimas modificaciones de importancia en el Patio con la profunda modificación de la concepción medieval del jardín, la eliminación de cimacios de madera de origen islámico y la inclusión de yeserías platerescas en los pilares y arquerías junto con las decoraciones de sebka y palmas de influencia islámica (Marín 1990).

\section{Intervenciones del siglo XVII}

Durante el reinado de Felipe III únicamente se realizan algunas modificaciones, en 1599 de la fuente central del 
Patio y en 1619 la reposición de dieciséis balaustres de mármol (Marín 1990). En 1634 se refiere Rodrigo Caro (1634) a las obras que se acometieron en el jardín del Patio, llamando la atención sobre la blancura del enlosado de mármol, los arcos que se apoyan en columnas de orden corintio y la calidad de las yeserías, con dorados y colores que sirven como medio de ostentación de la grandeza e instrumento de "satisfacción, y admiración del deseo" (Caro 1634: 56), por lo que se conoce con mayor exactitud que las obras se encuentran finalizadas y con un aspecto similar al actual. La descripción que hace Álvarez (1849) en el siglo XIX, no difiere de la anterior, describiendo un Patio que cuenta con galería superior, en el que se incluyen decoraciones de influencia islámica y en la que se hace hincapié en los arcos que se apoyan sobre columnas de mármol pareadas.

En 1755, tiene lugar el terremoto de Lisboa que da lugar a una serie de desperfectos que afectan al Patio, por lo que tuvo que ser apuntalado en algunas zonas (Gestoso 1889). A lo largo del siglo XVIII se produce una falta de documentación que afecta a ciertos periodos, pero sí se conocen datos de comienzos del siglo XIX como la apertura del acceso directo desde el Patio de la Montería ya descrito, que supone la reforma de las arquerías principales (Tubino 1886) y la introducción de un arco escarzano de mayores dimensiones en cada uno de los vanos centrales de las arcadas perimetrales de la galería alta (Marín 1990).

Es a primeros del siglo XIX, entre 1813 y 1820, cuando se suceden una serie de intervenciones menores como el enjalbegado con cal de Morón y ya en 1820, la necesidad de componer los cuatro arcos principales del Patio (Chávez 2004). En 1843 se produce el hundimiento de algunas zonas de los corredores por lluvias después del huracán que en 1842 había dañado la planta baja, recogiéndose en el presupuesto realizado por Juan Manuel Caballero en 1845, las labores pendientes de realizar, como son, el resanado de la cornisa de yeso, la formación de la cornisa de mármol y la reposición de solería $\mathrm{y}$ alicatado, dándonos una idea, aunque no se llegaran a realizar estas actuaciones, de los deterioros sufridos en este corto periodo de tiempo (Chávez 2004). En el año 1846 vuelve a haber referencias dentro de unos presupuestos que especifican la necesidad de construcción del artesonado, el solado de olambrillas, resanado de paredes y cielo raso, limpieza y resanado de los arabescos, ejecución de la solería de mármol en la planta baja, composición de cornisas y enchapadura de los arcos centrales del piso alto, composición de su balaustrada y elaboración de paños de alicatado (Chávez 2004).
Es cierto que todos estos informes en los que se recogen las necesidades del palacio no aportan la relación de las obras, ya que Juan Manuel Caballero se dedicaría sólo a las zonas que amenazaban ruina, siendo ya más adelante, entre 1854 y 1857, cuando José de la Coba realizaría una serie de intervenciones de las que sí existe cierta documentación. En dicha documentación se explica el estado del Patio de las Doncellas, que lo describe con 24 arcos moriscos sostenidos por 52 columnas y cuatro grandes portadas que dan acceso una al Salón de Carlos V, otra al Salón de Embajadores, otra al Dormitorio de los Reyes Moros y "otra que forma el trono que según tradición servía al rey moro para recibir el tributo de las cien doncellas" (Chávez 2004: 520) sobre la que más adelante desarrollaremos ciertos datos. A raíz de este informe podemos conocer que se realizan una serie de intervenciones que abarcan la albañilería, la compleja eliminación de la cal de Morón, el vaciado en yeso de zonas destruidas del friso, la colocación de elementos faltantes en las portadas y el estucado de la zona dañada de los alicatados (Chávez 2004).

Las relaciones de intervenciones y necesidades de reparación son complejas y en algunos casos insuficientes, pero a partir de estos informes podemos establecer una visión general de las necesidades de mantenimiento del área. En 1869 con la incorporación como arquitecto en comisión de Francisco Contreras se llamaría la atención sobre los frisos en mal estado con algunos mosaicos desprendidos en la zona de la entrada del Patio (Chávez 2004). Estas mejoras supusieron la adecuación de esta zona del palacio que había estado en mal estado desde principios de siglo y que debido a su magnitud también contaría con desperfectos años después, entre 1880 y 1882 (Chávez 2004), cuando se producen una serie de desprendimientos en las yeserías que se irían interviniendo dentro de las labores de mantenimiento del palacio.

\section{Modificaciones en los accesos al Patio de las Doncellas}

Para estipular la relación del Patio de las Doncellas con las estancias de su entorno, es necesario aclarar los cambios que se producen en dicho Patio y en los cuatro accesos principales o portadas que vinculan este espacio con el interior del palacio. Partiendo de la inicial concepción privada del palacio de Pedro I, se puede comprender la estructura previa de jardín rehundido con que contaba el Patio de las Doncellas, que debió ser modificada al no 
llegar a concluirse el Cuarto de la Montería que acogería las funciones públicas propias de la corte (Almagro 2018). El Cuarto Real, como se denomina al palacio de Pedro I, debió asumir las funciones que en su caso no pudieron ser acogidas en el inacabado Cuarto de la Montería, por lo que el jardín rehundido que se ubicaba en el Patio de las Doncellas debió ser modificado rellenando la zona de los parterres, reduciendo la profundidad de la alberca y eliminando los remates en forma de $\mathrm{T}$, para finalmente, con la llegada de los Augsburgo, desaparecer completamente debido a las exigencias de la corte (Almagro 2018). La estructura inicial del jardín del Patio, corrobora su condición privada que debió ser modificada posteriormente, convirtiendo el Salón de Embajadores en área de recepción y salón del trono (Almagro 2018).

Una vez estipulada la condición privada del palacio que se va modificando en el tiempo, se debe hacer alusión a los accesos que existen entre la planta alta y baja del palacio de Pedro I y de este con el Palacio Gótico para comprender lo acaecido en el paramento este del Patio de las Doncellas. La relación entre ambas plantas se debía realizar mediante escaleras que arrancaban desde distintas zonas de la planta baja, lo que denota, según Almagro (2015a), la falta de continuidad de la planta alta del palacio en su concepción inicial. La primera escalera de acceso a esta planta en la crujía norte, denominada "pública", partiría desde el segundo vestíbulo de entrada al palacio; y la segunda, denominada "privada", estaría situada en el ángulo de una estancia que, inicialmente, sería un patio entre el Cuarto Real y el Cuarto del Caracol, a la que se debía acceder desde otro pequeño tramo de escalera situado en el corredor de acceso al Patio de las Doncellas desde el segundo vestíbulo (Almagro 2015a). Por otro lado, en la crujía sur se encuentran en la actualidad dos escaleras de acceso, situándose la primera en el lado oriental y la segunda en el occidental fuera de los límites que se suponen inicialmente al palacio de Pedro I (Almagro 2015a). La escalera oriental de la crujía sur, que quedaría ubicada junto al palacio de Alfonso X, fue modificada seguramente, según Almagro (2015a), por la ubicación en esta zona de la sacristía de la capilla del palacio alfonsí. La escalera situada junto al Palacio Gótico, acceso actual desde el Patio de las Doncellas, aparece numerada como proyecto de ejecución en el plano de Sebastian van der Borcht ya mencionado, por lo que la circulación desde el palacio de D. Pedro hacia el Palacio Gótico debía hacerse a través del patinillo desde el que arrancaba la mencionada escalera "privada" (Almagro 2015a).
Estos accesos establecen la relación necesaria entre los distintos espacios, que se verían modificados según las necesidades de cada usuario.

Las vinculaciones del Patio con otras zonas del palacio están marcadas por las cuatro portadas principales (Fig.1), la primera lo vincula con el Palacio Gótico, al menos como medianería con el mismo, la segunda con el Salón del Techo de Carlos V, la tercera con el Salón de Embajadores y la cuarta con la Cámara Regia. Estas conexiones quedarían enmarcadas por un arco central que se levantaría en cada uno de los lados de las arcadas perimetrales del Patio, dando un mayor énfasis a estas conexiones entre los distintos espacios que, aunque aparecerían en sus cuatro lados, en el paramento oriental, inicialmente no establecería ninguna vinculación con otras áreas.

En el paramento oriental del Patio, aparecen unos nichos como consecuencia de la existencia de torreones o contrafuertes del Palacio Gótico al que se adosa el palacio de Pedro I (Fernández 2015). El paramento 17E, denominación referida a la numeración de este espacio y su posición al este o levante del Patio, cuenta con una serie de documentación tanto gráfica como textual que posteriormente ha sido refrendada con técnicas experimentales, refiriéndose a la existencia de una serie de huecos, que, ya sean puertas o ventanas como se intentará definir, existieron con seguridad hasta el siglo XIX. Previamente a la construcción del palacio de D. Pedro existirían unos ventanales góticos que debieron ser cegados al encontrarse ubicados en la zona de los tejados que cubrían las galerías del Patio. Los huecos posteriores hacia el Patio debieron abrirse más tarde, posiblemente cuando se abren las ventanas al jardín desde el Cuarto del Caracol. Aunque no se cuenta con documentación escrita sobre su apertura, debió ser previa a 1759, año en que aparecen en la planimetría de Sebastian van der Borcht de ese año. Como referencia gráfica inicial de estos huecos, se encuentra un dibujo de Justin Taylor editado entre 1826-1832 (Fig. 16) ${ }^{20}$, a través del cual se puede conocer la fecha aproximada en la que ya existirían estas aberturas (en dicha imagen se aprecian las del hueco central y el lateral izquierdo), como medio de comunicación con la capilla del Palacio Gótico.

De unos años más tarde, 1835, es el dibujo realizado por David Roberts, grabado por Challis, en el cual se plasma una perspectiva desde el Salón de

\footnotetext{
20 Taylor 1826-1832. Grande Cour de L'Alcazar de Séville [Dibujo]. [en línea] ark:/12148/btv1b86267575 [consultado el 10/02/2017].
} 


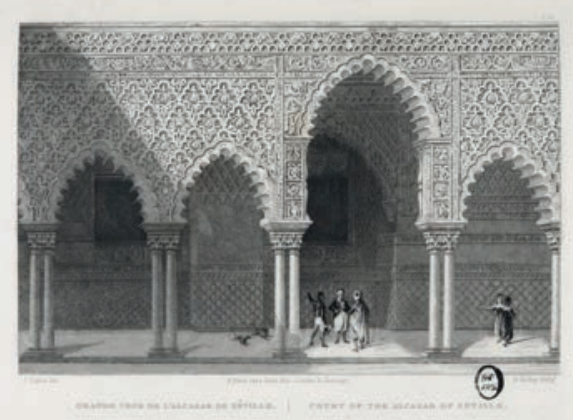

Figura 16. Paramento este del Patio de las Doncellas del Alcázar de Sevilla. Grande Cour de L'Alcazar de Sevilla.

Embajadores hacia el Patio de las Doncellas donde se observa al fondo el arco central del muro oriental del Patio con un balcón que comunica con el Palacio Gótico (Fig. 17) ${ }^{21}$.

Tomando como punto de partida estas ilustraciones, se puede establecer la existencia de los vanos a principios del siglo XIX, al menos desde 1826 con el dibujo de Taylor aunque se conoce que fueron anteriores. Dado que como ya se ha comentado no se cuenta con datos exactos en las hijuelas de la época sobre la apertura de las ventanas, se tiene que acceder a descripciones y documentación gráfica existente en este periodo. En este sentido se cuenta con otra ilustración realizada por Lerebours (Fig. 18) 2 $^{22}$ en torno a 1841, en la que se sigue observando un balcón en el hueco central del muro. Sin embargo, no se aprecia el hueco del lateral izquierdo que previamente sí habíamos observado en el dibujo de Taylor. Esta imagen tomada por Lerebours permitiría realizar una hipótesis sobre el proceso de apertura de los huecos, dado que las yeserías de la zona superior de formas curvas se repiten actualmente, por lo que o bien se produjo una yesería que se amoldara a estos huecos que luego se prolongaría en su cegado, o sería la ya existente recortada a la medida del balcón para posteriormente en su cegado colocar las yeserías faltantes en las que se aprecia una variación de color con respecto al resto (Fig. 19).

\footnotetext{
21 Roberts y Challis 1835. Entrance to the Hall of Ambassadors. Alcazar at Seville (1835) [Grabado] [en línea] http://www.bibliotecavirtualdeandalucia.es/catalogo/es/consulta/registro.cmd?id=1000765 [consultado el $30 / 05 / 2014]$.

22 Lerebours 1840-1843. Alcazar de Seville [Daguerrotipo] [en línea] http:// catalogue.bnf.fr/ark:/12148/cb33379774d [consultado el 09/12/2016].
}

Mediante la documentación gráfica aportada se continúa con los textos que se refieren a la fisionomía de este patio, como el realizado por José Amador de los Ríos, que lo describiría como patio o "alfagia" (De los Ríos 1844: 62) refiriéndose al muro oriental con los tres arcos o huecos que se han descrito, llamando la atención sobre el central y su balcón hacia la capilla del Palacio Gótico, junto con los laterales a los que José Amador de los Ríos les incluía balcones de similares características al central. Con esta descripción se pone en duda la existencia o no del balcón en el hueco de la derecha, que si bien pudo existir quizás no fuera abierto desde un principio.

En relación a los arcos centrales del Patio, sería únicamente el muro de levante el que no contaría con acceso directo a otras zonas, ya que la puerta de acceso al $\mathrm{Pa}-$ lacio Gótico se encuentra en el muro sur del Patio, en su esquina izquierda, aunque por las aberturas que se han definido en el paramento oriental, se podría decir que esta zona también comunicaría con otras, en este caso con el Palacio Gótico, considerado un área pública del Alcázar. En relación a la vinculación entre los palacios se encuentra un dibujo realizado en 1849 por Eduard Gerhardt, en el que se ilustraba la visita y estancia de los duques de Montpensier en Sevilla, donde se puede observar la presencia de una escalera que uniría ambos palacios al menos en ese momento concreto (Fig. 20) ${ }^{23}$.

Para apoyar lo que se ha observado en la ilustración anterior realizada por Gerhardt, contamos con una fotografía que corrobora la existencia de la escalera en el hueco central del muro oriental del Patio de las Doncellas, donde también se aprecia el balcón en el hueco izquierdo del muro, deduciéndose que tanto el balcón izquierdo como la escalera existirían al menos desde 1849 hasta 1852, fecha de esta última imagen de Emmanuel Pecquerel (Fig. 21) ${ }^{24}$.

Sobre estas aberturas también existen referencias escritas, como la realizada por Madrazo en 1856, que aunque está fechada con posterioridad a la imagen de Masson de 1855 (Fig. 22) ${ }^{25}$ que ha servido para datar el cierre de los huecos, debió ser escrita previamente a las intervenciones realizadas por José de la Coba entre 1854 y 1857 , cuando se supone el cierre de los huecos.

\footnotetext{
23 Gerhardt 1849. Alcázar de Sevilla. Patio de las Doncellas. Duques de Montpensier e Infantita Isabel. 1849. [Dibujo] [en línea] http://alhambrapatronato.es/ria/handle/10514/252 29-03-2014 [consultado el 29/03/2014].

${ }_{24}$ Pecquerel 1852. View in the Alcazar. Seville [en línea] http://coleccionfff.unav.es/bvunav/i18n/consulta/registro.cmd?id=3132 [consultado el 30/04/2014].

25 Masson 1855. Patio de las Doncellas [Fotografía] [en línea] http://coleccionfff.unav.es/bvunav/i18n/consulta/resultados_busqueda.cmd?posicion=43 $\&$ forma=ficha\&id=4453 [consultado el 26/03/2014].
} 


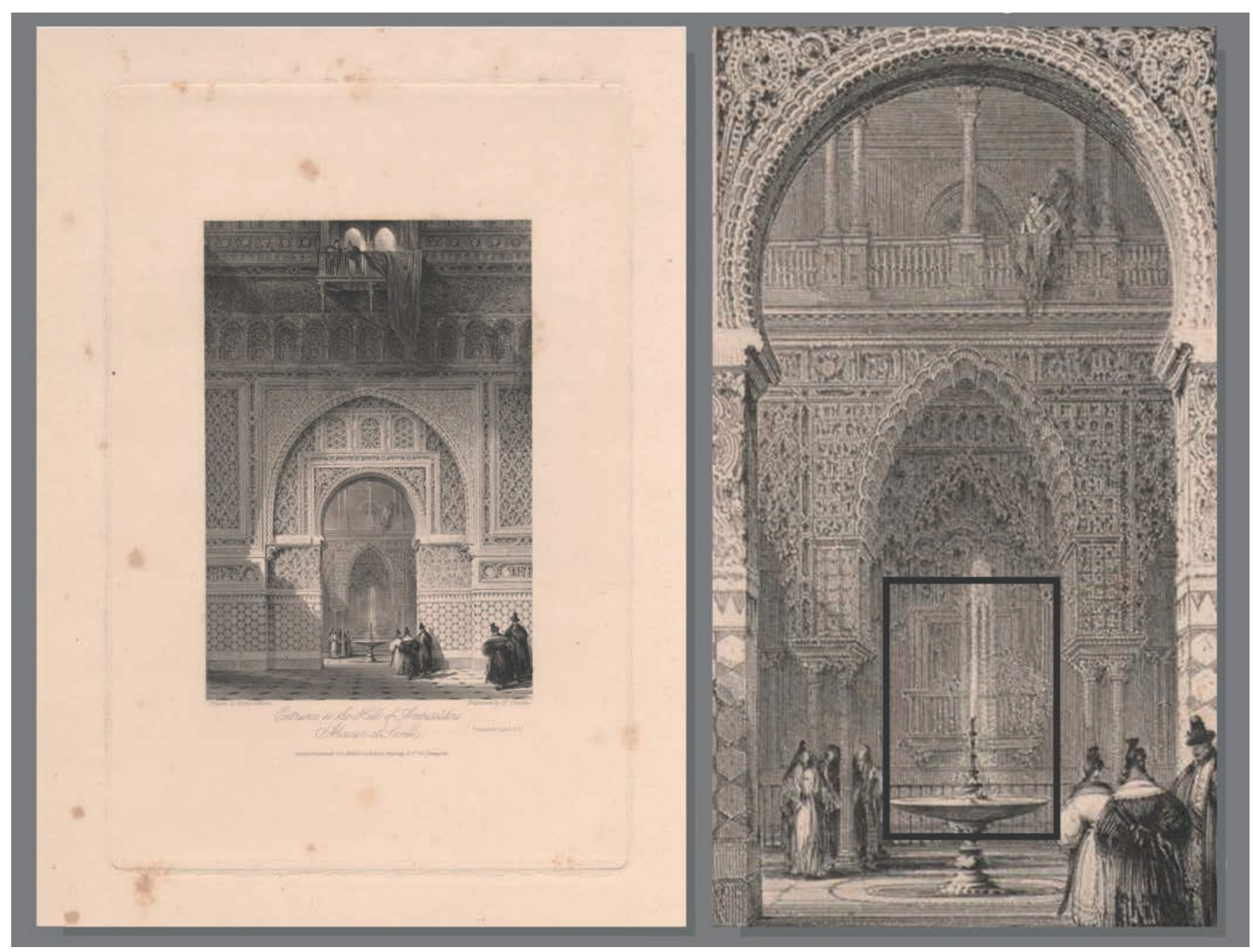

Figura 17. Vista desde el Salón de Embajadores hacia el muro oriental del Patio de las Doncellas con la ventana hacia el Palacio Gótico.

Madrazo (1856) describió los cuatro arcos principales del Patio, que dan acceso a diversas estancias. En primer lugar menciona el que sirve de entrada, que sería el que todavía contaría con el vano abierto a principios del siglo XIX en el vestíbulo de acceso y que serviría de línea de unión desde la fachada hasta los jardines posteriores. Por otro lado, los que llevan al Salón de Embajadores, al Salón del techo de Carlos V y por último menciona la Capilla baja, lugar donde se creía se encontraban las estancias de Doña María Padilla. En esta publicación, Madrazo (1856) hablaba de esos accesos refiriéndose al arco central de la portada de levante, que en dicha fecha contaría con la escalera que facilitaría el acceso, descartando la que todavía existe en la actualidad y a la que se accede por una pequeña puerta desde el muro sur del Patio. En las descripciones que se realizan sobre el Alcázar en 1858 (D. J. B. y M. de L. 1858) también se habla de los tres arcos que se levantan frente al Salón de Embajadores, mencionando la apertura de puertas a la capilla.

Otra referencia escrita a estos arcos de acceso del Patio de las Doncellas fue realizada por Caballero en el año 1863, describiendo lo que sería el Trono del Tributo, refiriéndose a la zona del muro medianero con el Palacio Gótico como el lugar donde se colocaría el trono de los Reyes Moros para que les pagaran el "tributo de las cien doncellas" por la ayuda prestada al Rey de Asturias Maregalo para llegar al trono (Caballero 1863). Caballero (1863) con estas palabras hace referencia al origen del nombre del Patio de las Doncellas, dejando claro que en esta época ya no existiría ninguna conexión con el Palacio Gótico y vinculando esta zona a la previa colocación de un altar (Manzano y Gámiz 2008).

En las referencias posteriores al cierre de estas aberturas se aclara su naturaleza ya que D. Rodrigo Amador de los Ríos (1875) las volverá a describir en 


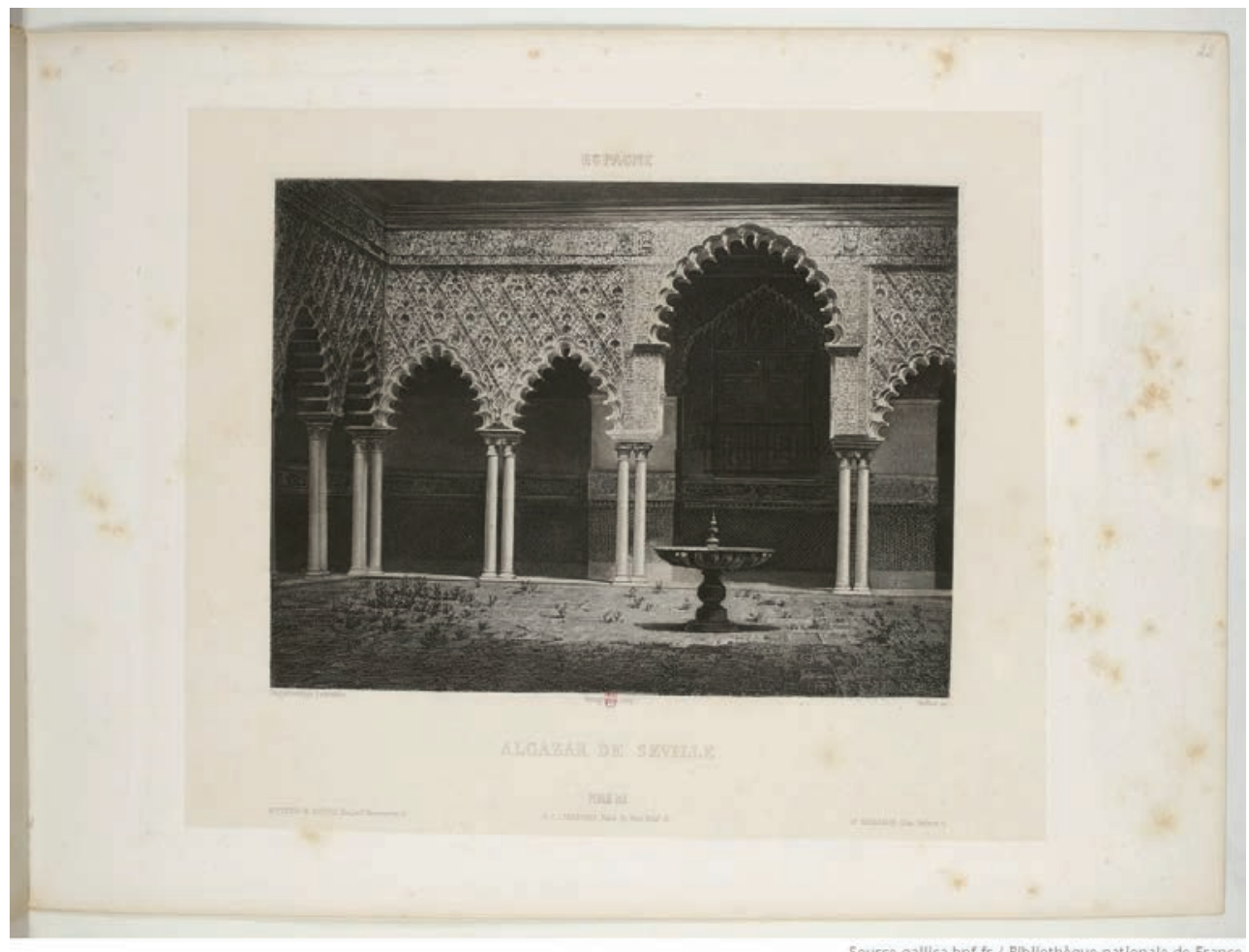

Figura 18. Patio de las Doncellas del Alcázar de Sevilla, entre 1840-1843, daguerrotipo de Lerebours dentro de la publicación "Excursions daguerriennes: vues et monuments les plus remaquables du globe".

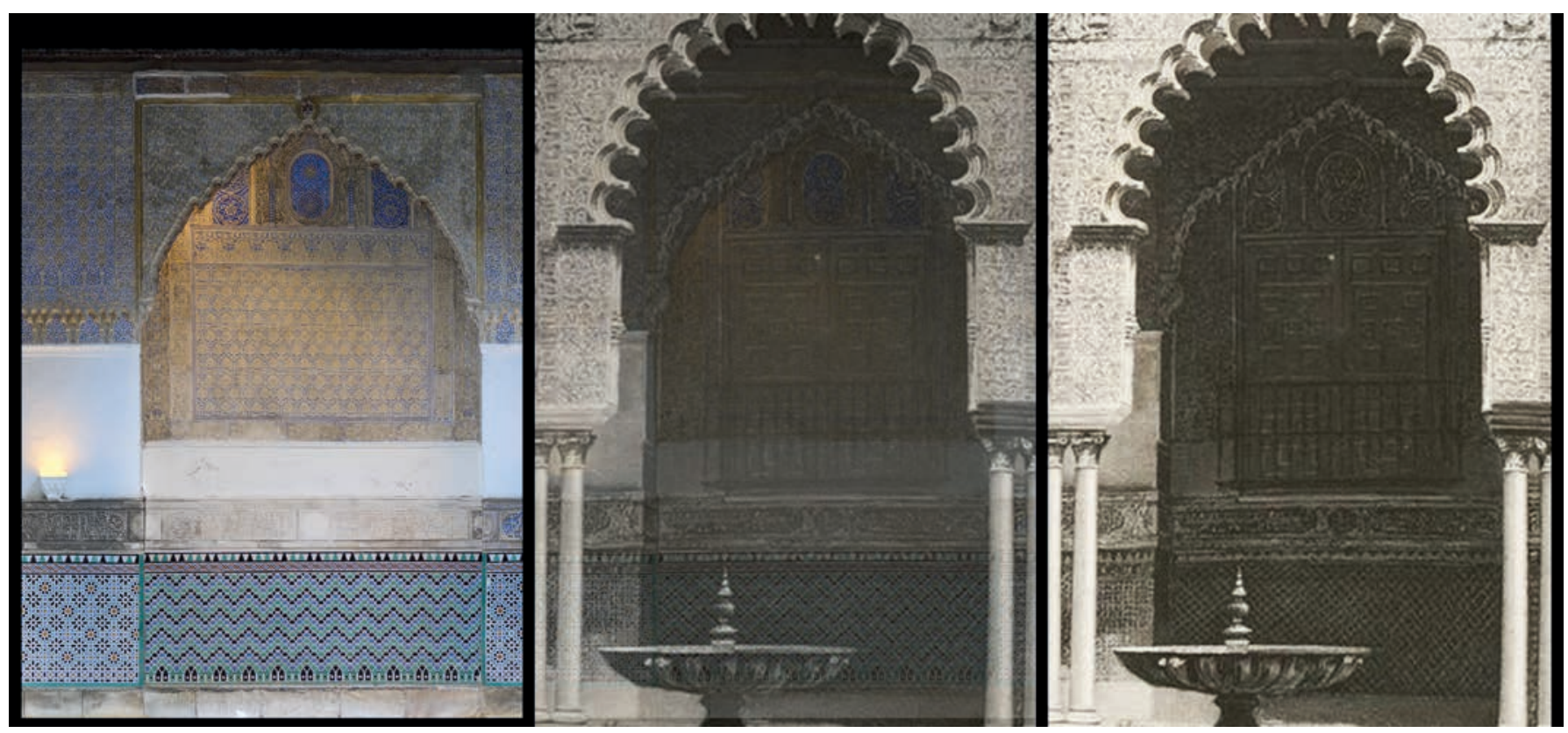

Figura 19. Comparativa entre ortofoto del hueco central del muro 17E del Patio de las Doncellas con imagen histórica de Lerebours del mismo paramento. 


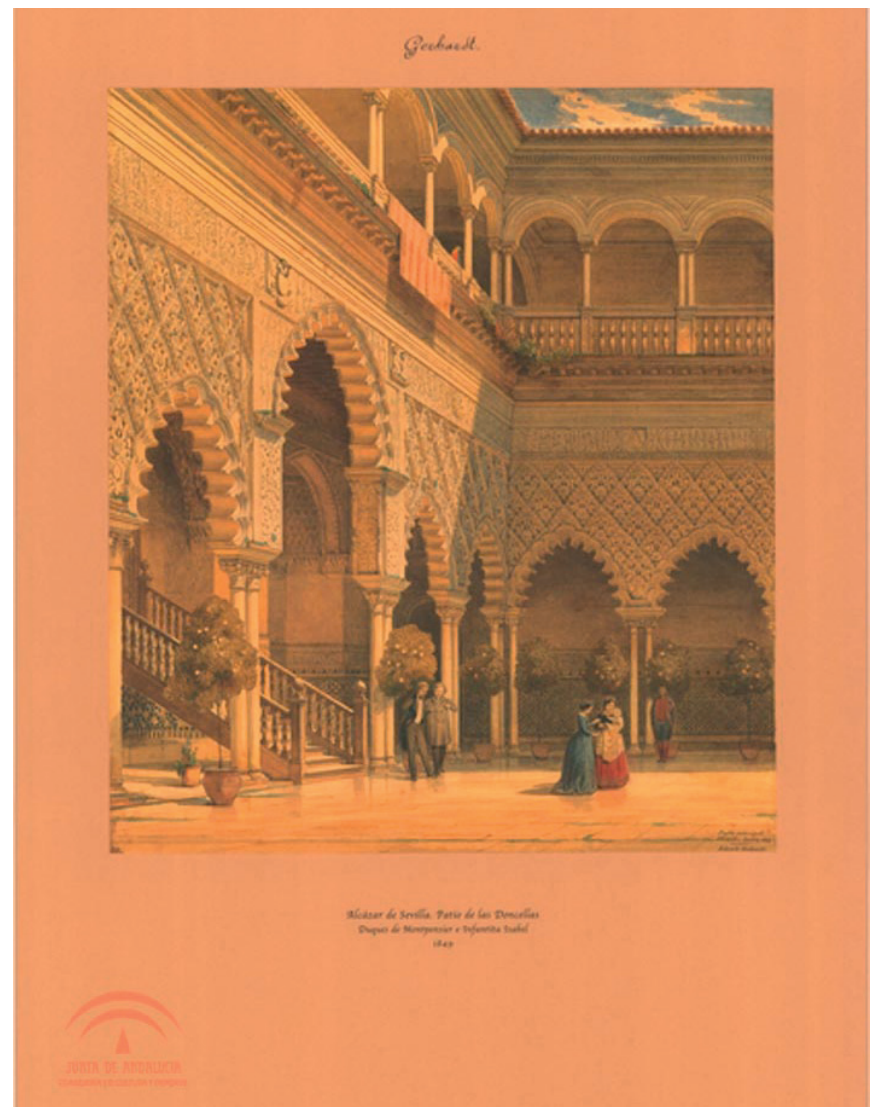

Figura 20. Patio de las Doncellas en 1849.

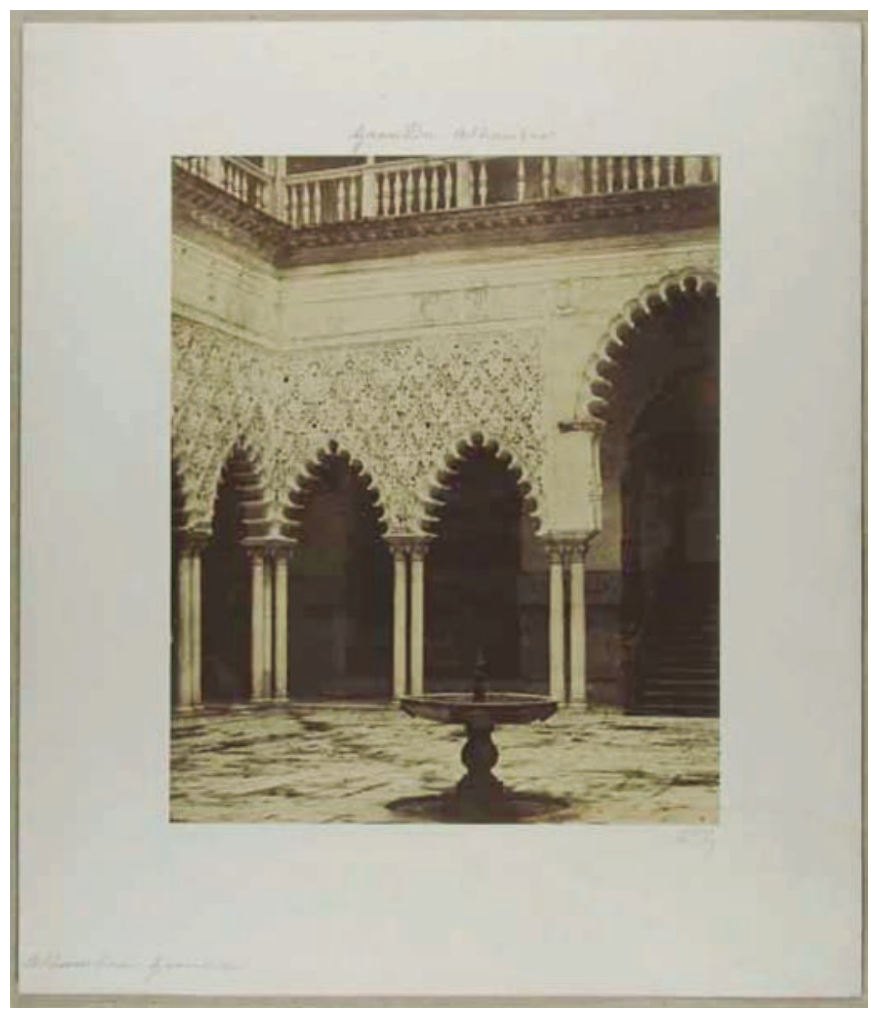

Figura 21. Muro oriental del Patio de las Doncellas, imagen tomada por Emmanuel Pecquerel en 1852.

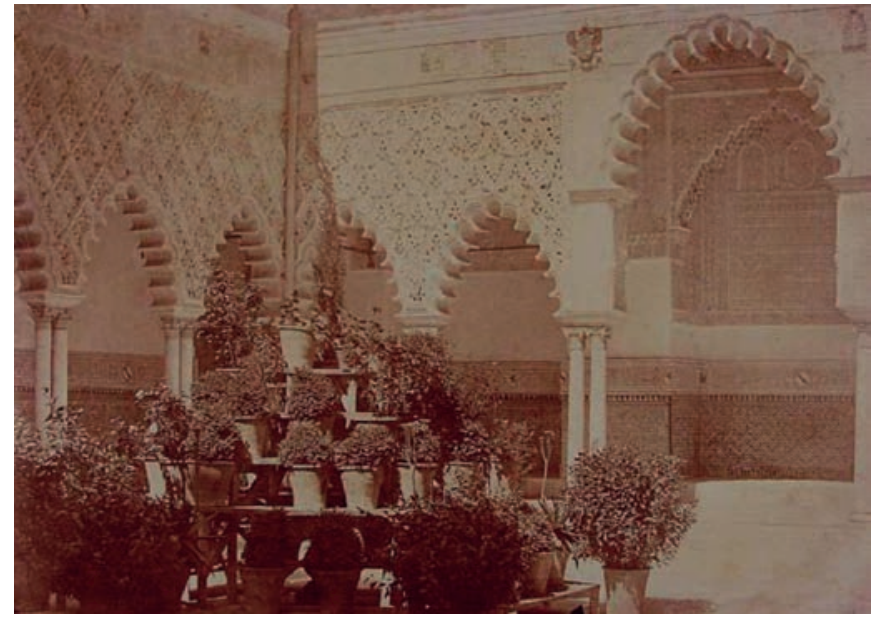

Figura 22. Patio de las Doncellas en 1855 procedentes del Fondo Fotográfico, Museo Universidad de Navarra, Pamplona.

1875 refiriéndose al salón del Palacio Gótico "convertido en Capilla, cuya puerta [...], es hoy el alhamy designado con nombre de Trono del Tributo" (De los Ríos 1875: 132-133) estableciendo aquí claramente su condición de puerta de acceso.

Para ilustrar la historia de este alhamy, como lo denomina D. Rodrigo Amador de los Ríos, este incluye en su obra Inscripciones árabes de Sevilla (1875) un plano de la planta baja del palacio de D. Pedro (Fig. 23), en el que ya se encuentran cerradas las aberturas de conexión, numerando a la central con el número seis y denominándola como Trono del Tributo (De los Ríos 1875). Considera el cierre de estos huecos producto de las últimas restauraciones realizadas en el Alcázar, que estarían abiertos en 1843 y que serían cegados de forma discreta, considerando que ésta sería la cuarta estancia con que contaría el Patio, que daba acceso a la Capilla, teniendo antes de su cierre características similares a las portadas del Dormitorio de los Reyes Moros, del Salón de Embajadores y del Salón del Techo de Carlos V, las otras tres portadas principales del Patio (de los Ríos, 1875).

De esta misma época se dispone de dos planos muy similares (Fig. 24) el primero incluido por Castillo (2001) en su estudio sobre la política constructiva de los Reyes Católicos. Este primer plano muestra la morfología del palacio en la primera mitad del siglo XIX por las aberturas que encontramos: vanos en la fachada en el margen derecho de la imagen, acceso desde la fachada hacia el interior del Patio de las Doncellas también en ese lado, realizado en 1806, y por último el vano de acceso a la capilla del Palacio Gótico, zona denominada por Rodrigo Amador de los Ríos (1875) como alhamy, sala alargada de la parte inferior de la imagen. Este plano es muy 
similar al segundo incluido en 1875 por Rafael Contreras (1875) en el que ya se observaba el acceso cerrado hacia el Palacio Gótico en la zona inferior de la planta (Fig. 24). En dicha publicación Contreras recogía sobre el Patio de las Doncellas lo siguiente: "Marcadas puertas en sus frentes conducen al Salón de Carlos V, de Embajadores, y á los del Caracol o de D ${ }^{a}$ María de Padilla" (Contreras 1875: 86), cuestión que llama la atención por referirse a los frentes y no a puertas laterales como la que en la fachada sur del palacio da paso al Palacio Gótico.

Otra de las descripciones referidas a esta zona del palacio, es la realizada por Rafael Contreras (1878) en la cual menciona los tres "nichos" que se ubicarían en el lado de la capilla, que se suelen relacionar con tronos del rey D. Pedro y que para este autor son los pasadizos ahora cegados que comunicaban el Patio con "el serrallo" (Contreras 1878: 113) situados frente al Salón de Embajadores. Años más tarde, Madrazo (1884) describía esta zona refiriéndose a los arcos centrales y a las puertas que se abren hacia la galería, incluyendo en su descripción el espacio que queda cerrado y que llama Trono del Tributo, junto con las otras tres ya conocidas.

Las últimas referencias sobre esta zona son las dadas por Tubino (1886) en relación al muro medianero entre la Capilla del Palacio Gótico y el Patio de las Doncellas del palacio del Rey Don Pedro. Atestigua que en el pasado estas dos construcciones se comunicaron por este muro, mencionando que el lugar donde se producía esta comunicación era el trono donde se recibía el tributo de las cien doncellas que los cristianos entregaban cada año. En referencia a esta abertura cita a José Amador de los Ríos y su obra Sevilla Pintoresca (1844), donde los considera abiertos en 1843 y puntualizando la existencia de otros dos laterales (Tubino 1886). De

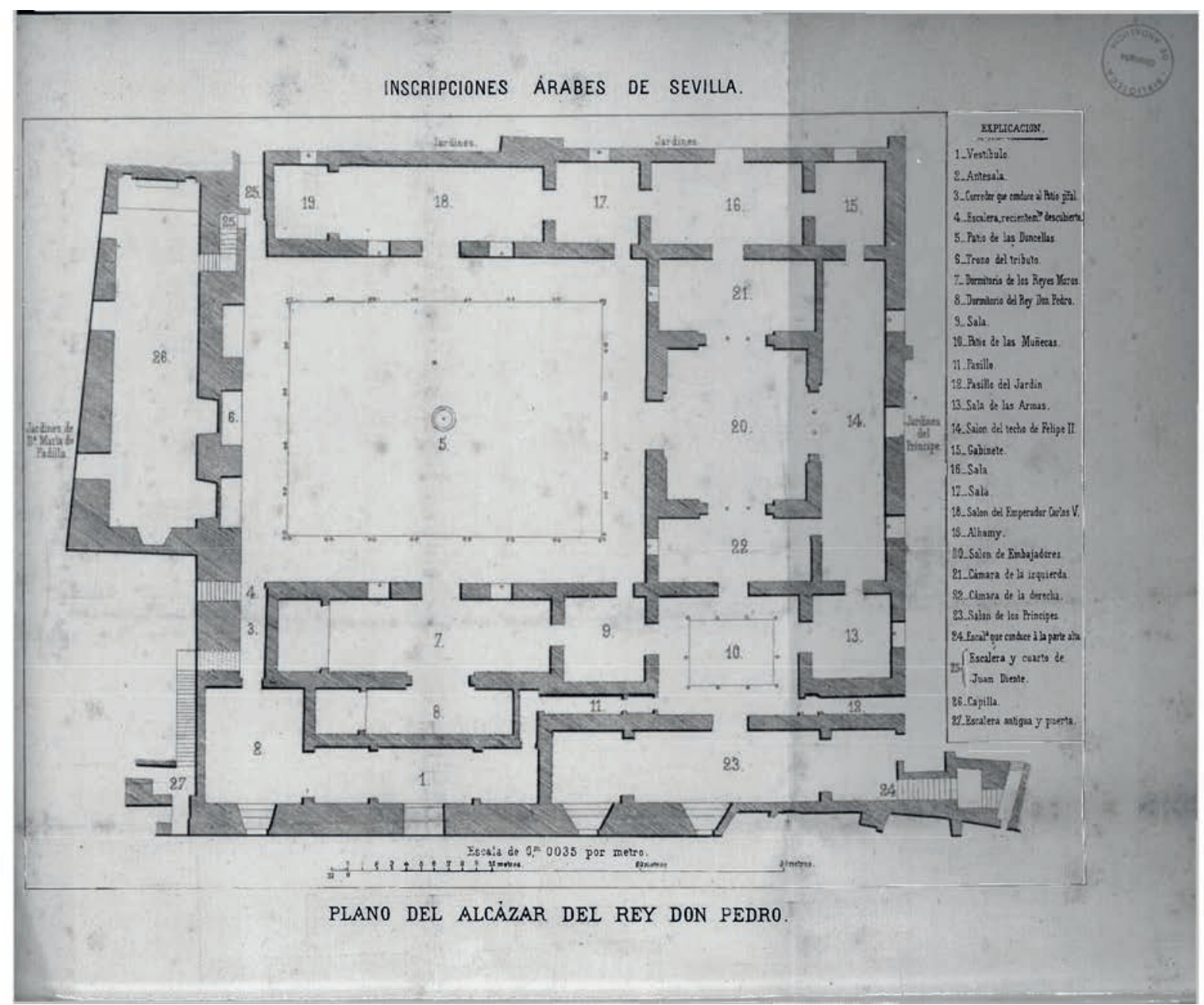

Figura 23. Plano de la planta baja del palacio de D. Pedro donde se señala la zona del posible acceso al Palacio Gótico denominado en la leyenda como Trono del Tributo (De los Ríos 1875). 


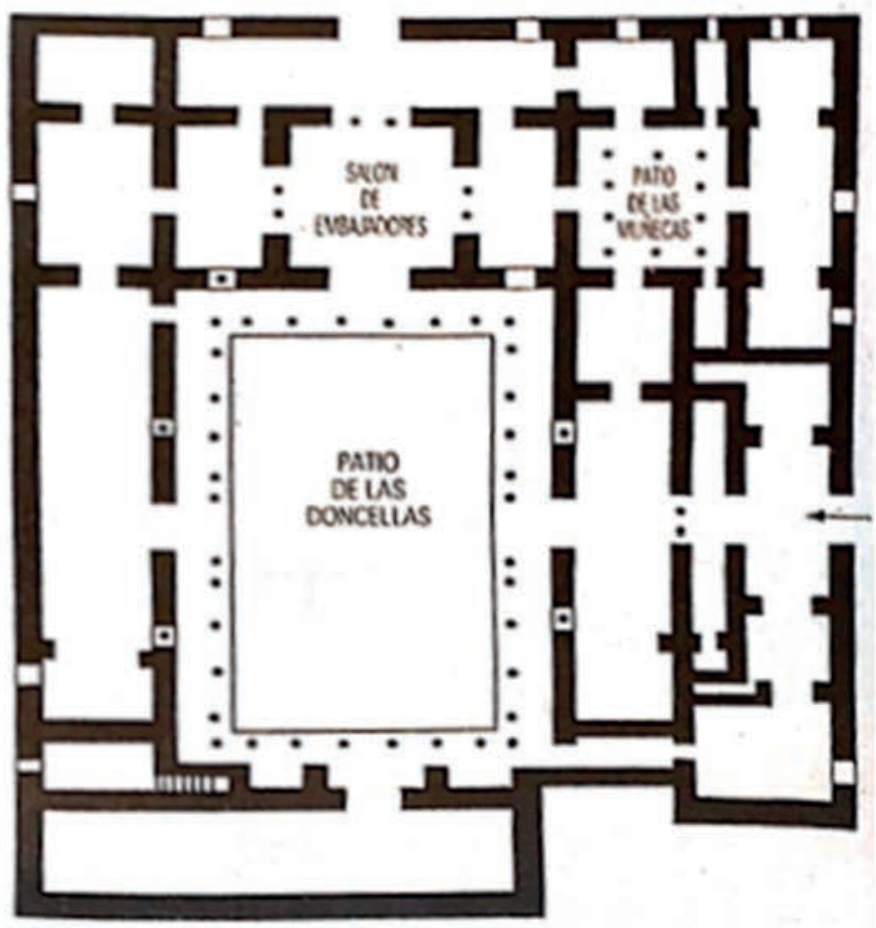

PLANTA DEL PALACI DE PEDRI I (CASTILLD, 20ם1)

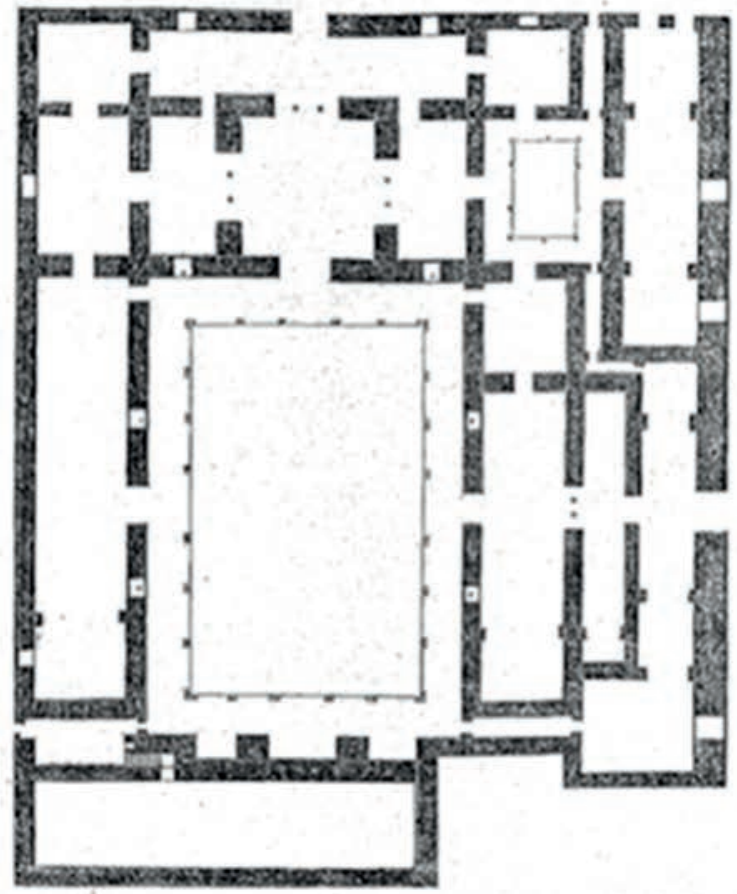

PLANTA DEL PALACI DE PEDRD I (CINTRERAS, 1875 )

Figura 24. Comparativa entre planos de la planta baja del palacio de Pedro I incluidos por Castillo (2001) y Contreras (1875) en sus publicaciones.

la época en que Tubino escribió sobre este palacio contamos con un dibujo de 1888 (Fig. 25) ${ }^{26}$ en el que ya se observa el macizado definitivo de los huecos.

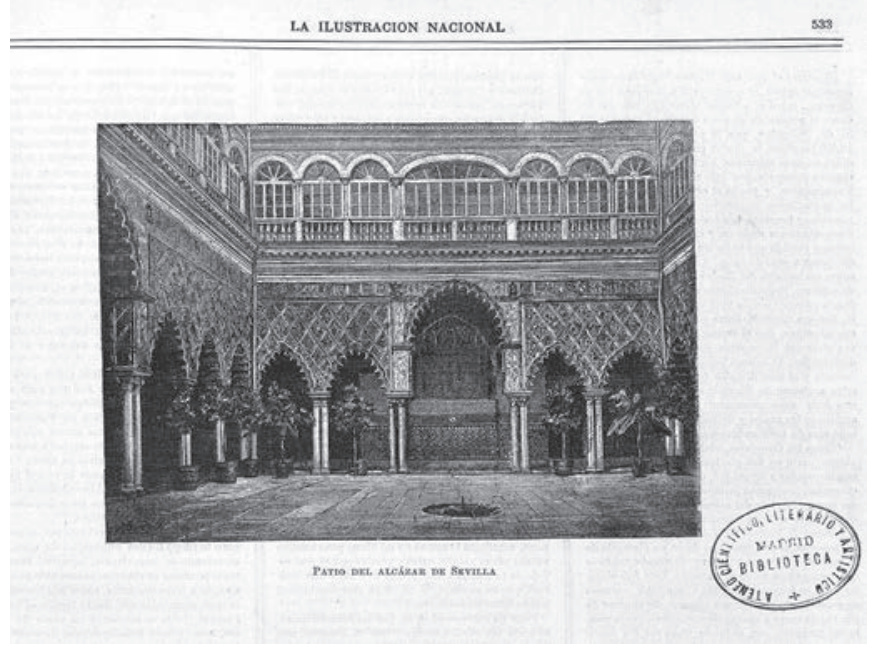

Figura 25. Patio del Alcázar de Sevilla publicado en La Ilustración Nacional.

${ }_{26}$ Ilustración Nacional 1888. Patio del Alcázar de Sevilla [Dibujo] [en línea] http://prensahistorica.mcu.es/es/consulta/registro.cmd?id=6127 [consultado el 30/03/2014]. Ilustración Nacional 1888: La Ilustración Nacional: revista literaria, cientifica y artística, tomo I, año IX, 34, diciembre.

\section{Estudio termográfico del paramento este del Patio de las Doncellas}

Un análisis comparativo entre la documentación histórica y los estudios termográficos, permite entender mejor el proceso de transformación del palacio y en concreto de esta zona del Patio. La vinculación entre la documentación histórica previamente reseñada, el estudio fotogramétrico y el análisis termográfico, se podría resumir a través de una imagen en la que se superpone la ortofoto resultante del estudio fotogramétrico, la imagen termográfica en la parte izquierda y una imagen histórica (en este caso la realizada por Pedrosa a mediados del siglo XIX) en la parte derecha (Fig. 26) ${ }^{27}$.

El estudio termográfico realizado en el paramento 17E, muro este del Patio de las Doncellas (Figs. 27 y 28), se ha realizado a dos distancias diferentes debido al espacio disponible en el Patio y a las posibilidades de la cámara utilizada. La imagen general realizada desde

\footnotetext{
27 Pedrosa 1857. Alcázar de Sevilla. Patio de las doncellas [Fotografía] [en línea] http://www.museunacional.cat/es/colleccio/alcazar-de-sevilla-patiode-las-doncellas/joaquim-pedrosa/214171-000 [consultado el 30/04/2014].
} 


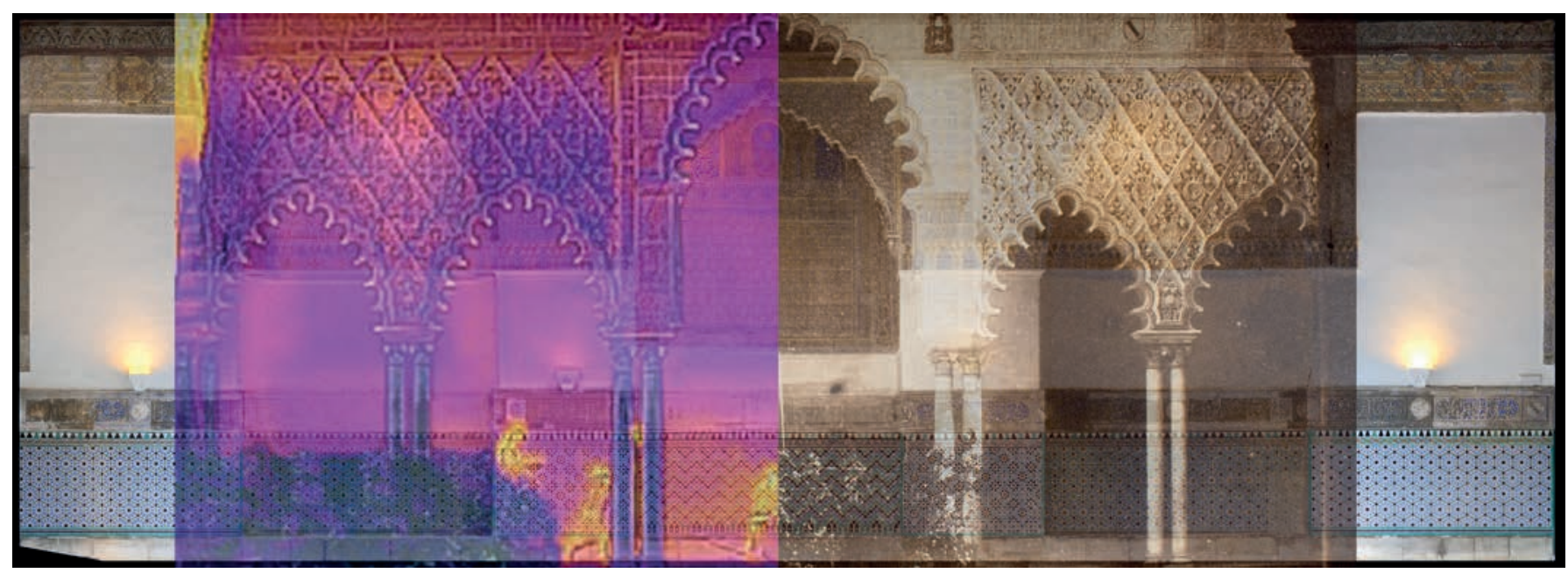

Figura 26. Montaje realizado con fondo formado por ortofoto de elaboración propia, imagen termográfica e imagen histórica de Pedrosa.

el corredor opuesto a este paramento, nos muestra que en cada uno de los vanos existiría una abertura hacia el Palacio Gótico (Fig. 27). En esta toma el hueco derecho aparece con menor nitidez por la menor disminución de temperatura con respecto al espacio circundante. Esto puede ser debido al mayor grosor del muro que en el caso del central y el izquierdo no debe superar los $30 \mathrm{~cm}$ $\mathrm{y}$ por otro a las diferentes condiciones de temperatura y humedad relativa cuando se realizó la toma. La temperatura y humedad ambiental son responsables del mayor o menor contraste en los falsos colores relacionados con el infrarrojo, dado que con mayor humedad y a temperatura más baja se definen mejor los contornos. Este es el caso de las imágenes tomadas en el Patio de las Doncellas,

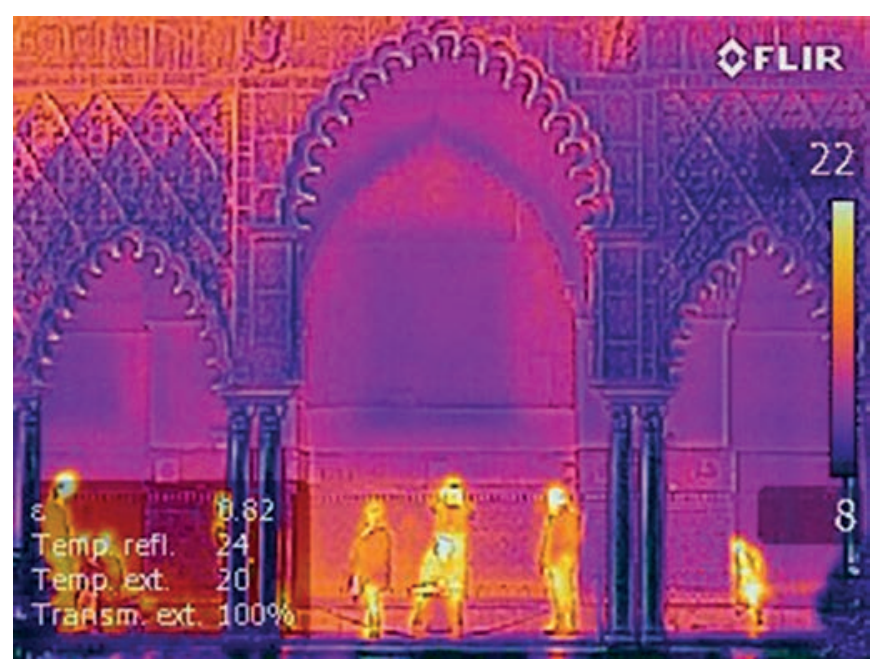

Figura 27. Estudio termográfico general del paramento 17E del Patio de las Doncellas (25-febrero-15, ta $14.6-16.3{ }^{\circ} \mathrm{C}$, HR 52-47\%). ya que como se observa en la figura 27 tomada el día 25 de febrero de 2015 a una temperatura que oscilaba entre 14.6 y $16.3{ }^{\circ} \mathrm{C}$ y con una humedad relativa comprendida entre un 52 y un $47 \%$ entre las 12 horas y las 13 horas, no se aprecia claramente el hueco en el nicho derecho. Sin embargo, cuando se realizó el segundo estudio el día 9 de noviembre de 2016 a una temperatura que oscilaba entre 15.4 y 17.8 y una humedad relativa entre 72 y $67 \%$ entre las 12 y las 13 horas, se observa con mayor nitidez el vano derecho (Fig. 28). Este estudio termográfico nos ha permitido asegurar la presencia de los huecos practicados en el muro este del Patio de las Doncellas apoyándonos en tres vertientes distintas tanto histórica, gráfica como técnica.

\section{CONCLUSIONES}

Las modificaciones acaecidas en los vestíbulos de acceso al palacio de Pedro I, cambiaron la disposición inicial del mismo, ya que en los inicios de su construcción los espacios se conciben mediante un principio fundamental de intimidad, dado que inicialmente era un palacio privado, y no iba a estar destinado a funciones públicas. A través de las investigaciones llevadas a cabo en el Patio de las Doncellas, se puede comprobar la importancia de la relación entre los estudios históricos y los técnicos con el uso, por ejemplo, de la fotogrametría y los propios de ciencias experimentales como es el caso de la termografía infrarroja. La relación de las diferentes metodologías de estudio enriquecen los resultados finales de la investigación, coincidiendo la documentación 


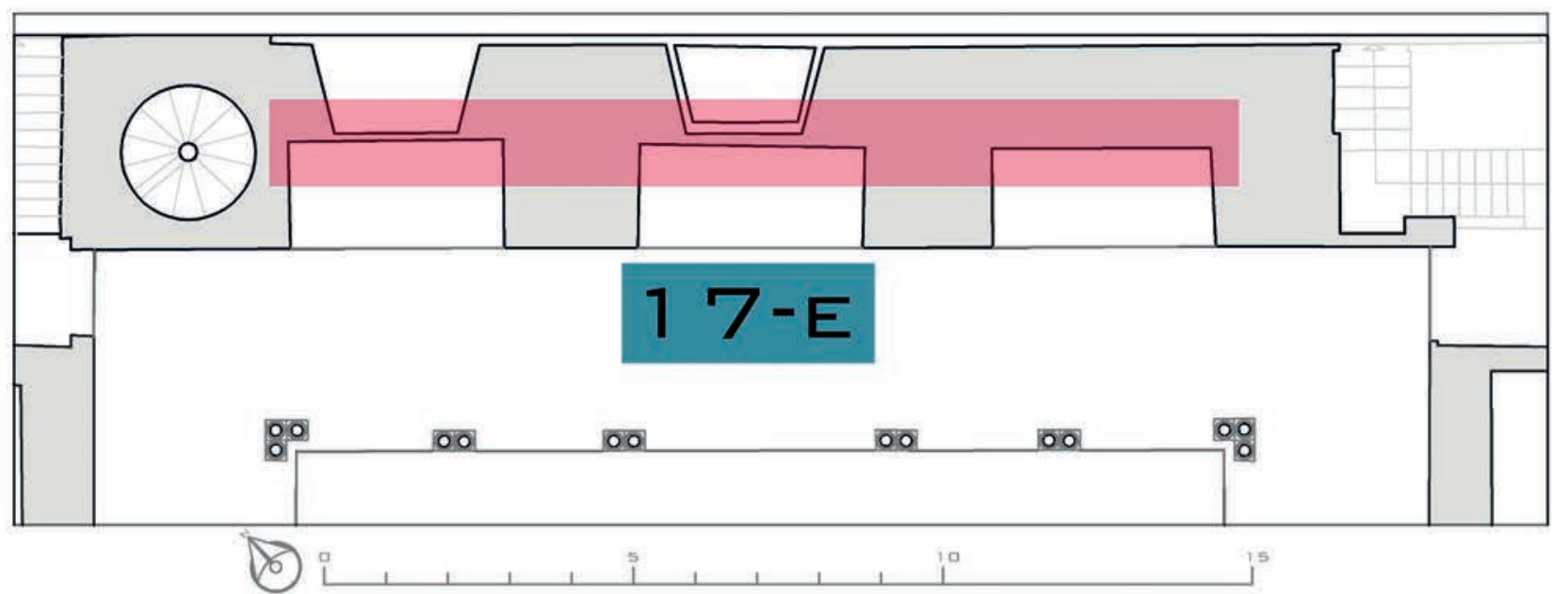

PARAMENTI ESTE PATI DE LAS DINCELLAS PALACII PEDRI I REAL ALCÁZAR SEVILLA TERMIGRAFÍA INFRARRIJA

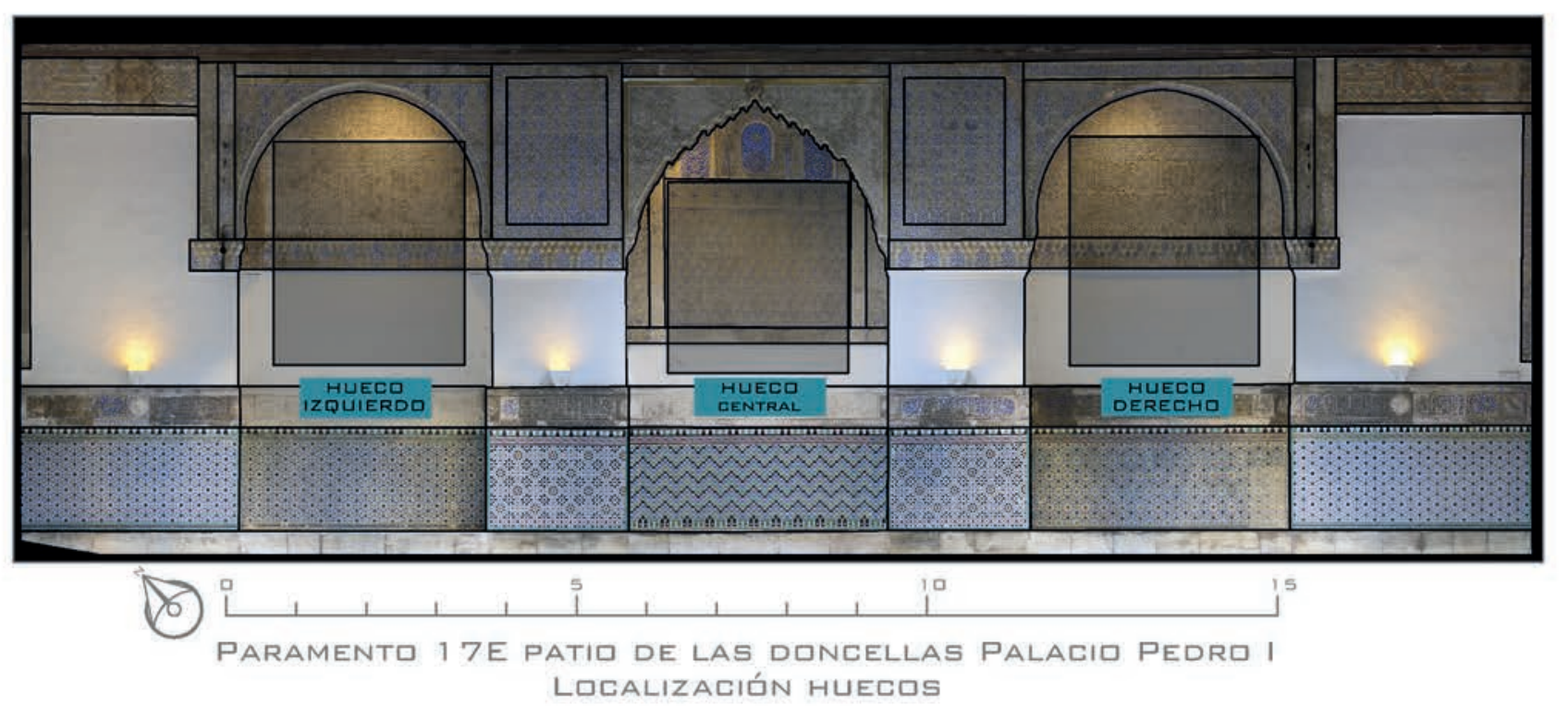

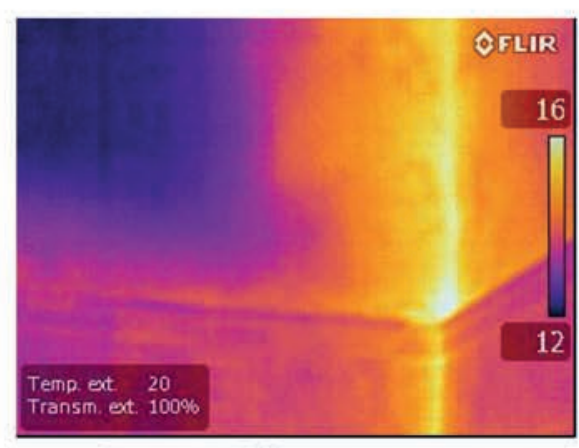

PARAMENTO 17 E HUECL IZQUUERDI TERMLISRAFIA INFRARROJA
9-NOV.-16. T. $15.4-17.8$ C. HR $72.67 \%$

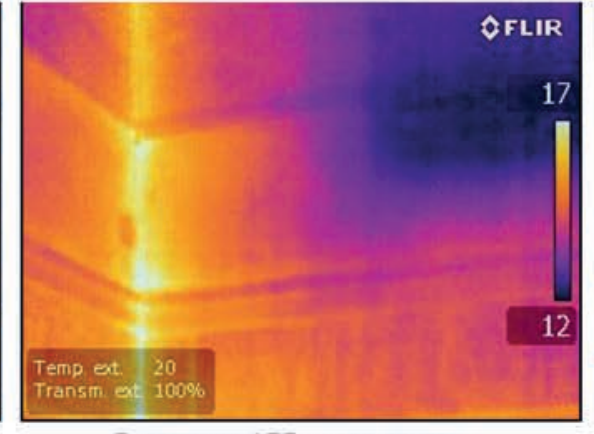

PARAMENTO 17 E HUECD CENTRAL

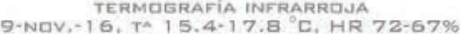

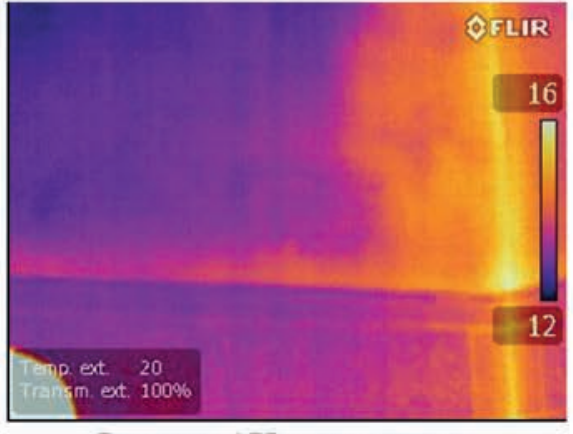

PARAMENTD 17 E HUECD DERECHI TERMDISRAFIA INFRARRDJA
9.NOV.+16. TA $15.4-17.8^{\circ} \mathrm{C}$, HR $72.67 \%$

Figura 28. Zonas de estudio termográfico en el paramento 17E del Patio de las Doncellas del palacio de Pedro I. Real Alcázar de Sevilla. Ubicación de huecos practicados en el muro hacia la capilla del Palacio Gótico. 
histórica recogida con los análisis realizados a los paramentos mediante termografía infrarroja, aportando una escala real a las intervenciones que se conocían mediante documentación gráfica de carácter histórico.

La entrada por la fachada principal hacia las estancias del palacio se producía en recodo desde la construcción del palacio, con una finalidad, por tanto, puramente encaminada a preservar la intimidad del círculo de la corte. Esta tipología circulatoria que se observa en el palacio de Pedro I no es del todo comprendida en una sociedad cristiana, como atestiguan las palabras de Caballero (1863) tras el cierre por parte de José de la Coba del acceso directo, ya que no ve en esta entrada la grandeza del palacio que aguarda tras ella, especificando que existe una pared que priva de la visión del Patio de las Doncellas, al que se accede a través de una puerta lateral de pequeñas dimensiones.

La relación visual del palacio de Pedro I con el exterior se realizaría a través de la qubba presente en la planta alta y sus ventanas hacia el Patio de la Montería y no se incluían ni las ventanas, que se abrirían a lo largo del siglo XIX en los vestíbulos, ni puertas de acceso directo hacia la zona privada del palacio. La vinculación de las estancias entre sí y estas con el exterior va más allá de la estructura de entrada en recodo y, como se ha podido comprobar, fueron ampliamente modificadas ya desde el siglo XVI cuando se transforma y enlosa el Patio de las Doncellas.

La comunicación entre el Patio y la actual capilla del palacio alfonsí, que hasta donde se conoce no tuvo tal uso hasta el siglo XVIII, era imposible de forma directa como lo demuestra la escalera de madera que fue construida en el siglo XIX y ubicada en el nicho central del paramento este del Patio. Se comprueba que con la colocación de esta escalera en dicho paramento se modificarían las comunicaciones entre este palacio de Pedro I y su contiguo, el Palacio Gótico. Este paramento, al posibilitar la conexión entre el Patio de las Doncellas y el palacio alfonsí, conformaría un espacio idóneo de conexión más directa.

A través de estas investigaciones, se ha podido comprobar la importancia de relacionar los diferentes campos de estudio, teniendo como objetivo último la conservación de nuestro patrimonio en las mejores condiciones, pasando para ello por establecer puntos de importancia para mejorar el conocimiento que en la actualidad tenemos del mismo y los recursos que se aplican para profundizar en dicho conocimiento. Se deben para ello valorar todos los elementos que lo conforman, considerando también la necesidad de involucrar en ello a la sociedad actual, así como establecer la creación de equipos interdisciplinares que deben unirse en la búsqueda de una metodología común y eficaz para el estudio de estas edificaciones.

\section{AGRADECIMIENTOS}

Este trabajo forma parte de un estudio más amplio, que constituye la Tesis Doctoral en curso que se está desarrollando en la Universidad de Granada por parte de la primera autora, en la que se realiza un análisis e identificación de las intervenciones que se han llevado a cabo en el palacio de Pedro I del Real Alcázar de Sevilla. El trabajo ha sido financiado por los proyectos de investigación MAT2016-75889-R y grupo RNM-179 de la Junta de Andalucía. Agradezco al Real Alcázar de Sevilla la disponibilidad para la realización del análisis fotogramétrico y termográfico y a la Escuela de Estudios Árabes del CSIC la estancia de investigación que pude en ella realizar.

\section{BIBLIOGRAFÍA}

Almagro Gorbea, A. (coord.) 2009b: "La portada del Palacio de Pedro I. Investigación y restauración”, Apuntes del Alcázar de Sevilla, 10, pp. 6-49.

Almagro Gorbea, A. 2007: "Los palacios de tradición andalusí en la Corona de Castilla: las empresas de Pedro I", en M. V. Fernández (coord.), Actas del Simposio Internacional El legado de al-Ándalus: el arte andalusí en los reinos de León y Castilla durante la Edad Media, pp. 243-282. Fundación del Patrimonio Histórico de Castilla y León, Valladolid.

Almagro Gorbea, A. 2009a: "El Alcázar de Sevilla. Un palacio musulmán para un rey cristiano", Cristianos y Musulmanes en la Península Ibérica: La guerra, la frontera y la convivencia. XI Congreso de Estudios Medievales, 2007, León.

Almagro Gorbea, A. 2015a: "La planta alta del palacio de Pedro I en el Alcázar de Sevilla", Anuario del Departamento de Historia y Teoría del Arte, 27, pp. 69-115.

Almagro Gorbea, A. 2015b: "Los jardines andalusíes y mudéjares del Alcázar de Sevilla”, en A. Marín y C. Plaza (eds.), Los jardines del Real Alcázar de Sevilla. Historia y Arquitectura desde el Medievo islámico al siglo XX, pp. 1-39. Patronato del Real Alcázar de Sevilla y de la Casa Consistorial, Sevilla.

Almagro Gorbea, A. 2018: "El Patio de las Doncellas del Palacio de Pedro I, un jardín doméstico en la casa del rey”, en J. A. González Alcantud, Encuentro Leones y Doncellas, Dos patios andaluces en diálogo cultural (siglos XIV al XXI), Granada/Sevilla.

Almagro Vidal, A. 2005: El concepto de espacio en la arquitectura palatina Andalusí. Un análisis perceptivo a través de la infografía. Tesis doctoral europea. Universidad de Granada, Granada. ISBN: 84-338-3547-5.

Álvarez Miranda, V. 1849: Glorias de Sevilla. Càrlos Santigosa editor, Sevilla. Caballero, F. 1863: El Alcázar de Sevilla. Imprenta de D. A. Izquierdo, Sevilla.

Caro, R. 1634: Antiguedades, y principado de la ilustrissima ciudad de Sevilla y chorographia de su convento ivridico, o antigva chancilleria. Andres Grande, Sevilla.

Castillo Oreja, M. A. 2001: "La conservación de un valioso legado: la rehabilitación de los alcázares reales en la política constructiva de los Reyes Católicos”, en M. A. Castillo (ed.), Los alcázares reales. Debates sobre Arte. Encuentros sobre Patrimonio, pp. 99-127. Fundación BBVA, Antonio Machado Libros, Madrid. 
Chávez González, M. ${ }^{a}$ R. 2004: El Alcázar de Sevilla en el siglo XIX. Ayuntamiento de Sevilla Patronato del Real Alcázar, Sevilla.

Contreras, R. 1875: Del Arte Árabe en España manifestado en Granada, Sevilla y Córdoba por los tres monumentos principales La Alhambra, El Alcázar y la Gran Mezquita. Imprenta de D. Indalecio Ventura, Granada.

Contreras, R. 1878: Estudio descriptivo de los monumentos árabes de Granada, Sevilla y Córdoba ó sea La Alhambra, El Alcázar y la Gran mezquita de occidente. Imprenta y Litografía de A. Rodero, Madrid.

D. J. B. y M. de L. 1858: Guía para visitar el Alcázar de Sevilla. Breve reseña histórico-descriptiva de este célebre edificio, en que se exponen sus tradiciones y los hechos más notables que en él han tenido lugar. Imprenta de la Revista Mercantil, Sevilla.

De los Ríos, J. A. 1844: Sevilla pintoresca o Descripción de sus más célebres monumentos artísticos. Francisco Álvarez y Ca, Sevilla.

De los Ríos, R. A. 1875: Inscripciones árabes de Sevilla. Imprenta de T. Fortanet, Madrid.

Fernández Aguilera, S. 2015: "Origen del Palacio de Pedro I en el Alcázar de Sevilla: el mirador hoy llamado de los Reyes Católicos", Archivo Español de Arte, LXXXVIII, 352, octubre-diciembre 2015, pp. 331-348.

Gestoso y Pérez, J. 1889: Sevilla monumental y artística: historia y descripción de todos los edificios notables, religiosos y civiles que existen actualmente en esta ciudad y noticia de las preciosidades artísticas y arqueológicas que en ellos se conservan por José Gestoso y Pérez. El Conservador, Sevilla.

Gómez-Heras, M. 2012: "La temperatura en los materiales del Patrimonio", en R. Fort González y E. M. Pérez-Montserrat (coords.), Curso Postgrado CSIC: La conservación de los geomateriales utilizados en Patrimonio, Madrid, mayo de 2011, pp. 87-96. Programa Geomateriales, Madrid.

Lerma, C., Mas, Á., Gil, E., Vercher, J. y Peñalver, M. J. 2013: "Pathology of building materials in historic buildings. Relationship between laboratory testing and infrared thermography", Materiales de Construcción, 64, 313, pp. 1-11.

Lleó Cañal, V. 2013: "El Alcázar", Apuntes del Alcázar de Sevilla, 14, pp. 20-29.
Madrazo, P. de 1856: Recuerdos y bellezas de España: bajo la Real protección de S.S.M.M. la Reina y el Rey: obra destinada à dar à conocer sus monumentos y antigüedades / en laminas dibujadas del natural por F. J. Parcerisa. Imprenta de Cipriano López, Madrid.

Madrazo, P. de 1884: España sus monumentos y artes - su naturaleza é historia. Sevilla y Cádiz. Establecimiento Tipográfico - Editorial de Daniel Corteza y $\mathrm{C}^{\mathrm{a}}$, Barcelona.

Manzano Martos, R. y Gámiz Gordo, A. 2008: "La arquitectura y el paisaje de Sevilla en las fotografías de J. Laurent", en Sevilla artística y monumental. 1857-1880. Fotografias de J. Laurent, pp. 56-91. Fundación Mapfre, Madrid. ISBN 978-84-8455-229-1.

Marín Fidalgo, A. 1990: El Alcázar de Sevilla bajo los Austrias. Ediciones Guadalquivir, Sevilla.

Marín Fidalgo, A. 2006: Felipe $V$ de Anjou, rey de las Españas: el Real Alcázar de Sevilla durante su reinado (1700-1746). Guadalquivir, Sevilla.

Morales, A. J. y Serrera, J. M. 1999: "Obras en los Reales Alcázares de Sevilla en tiempo de los Reyes Católicos", Laboratorio de Arte, 12, pp. 69-77.

Pleguezuelo, A. 2015: "Los alicatados del Palacio mudéjar en el Real Alcázar de Sevilla", Apuntes del Alcázar de Sevilla, 16, pp. 218-231.

Rodríguez Moreno, C. 2011: El palacio de Pedro I en los Reales Alcázares de Sevilla. Estudio y Análisis Tesis doctoral europea. Editorial de la Universidad de Granada, Granada. ISBN: 978-84-9028-124-6.

Tabales Rodríguez, M. A. 2003: "Investigaciones arqueológicas en el Patio de las Doncellas. Avance de resultados de la primera campaña", Apuntes del Real Alcázar, 4, pp. 7-25.

Tabales Rodríguez, M. A. 2010: "La investigación arqueológica en edificios históricos. Metodologías y experiencias El Alcázar de Sevilla”, en C. Martín Morales y E. de Vega García (coords.), Arqueología aplicada al estudio e interpretación de edificios históricos. Últimas tendencias metodológicas, pp. 159-177. Ministerio de Cultura, Madrid.

Tubino, F. M. 1886: La arquitectura hispano-visigoda y árabe española. El Alcázar de Sevilla. Una iglesia mozárabe. Segovia de los Ríos, Sevilla. 